\title{
长江中下游燕山期最新的成岩成矿事件: 来自宁镇地区的证据
}

\author{
孙洋 $^{(12)}$ ，马昌前 ${ }^{(1) *}$, 刘园园 ${ }^{(1)}$ \\ (1) 中国地质大学地球科学学院, 武汉 430074; \\ (2) 长江大学地球科学学院, 武汉 430100 ; \\ (3) 中国地质大学地质过程与矿产资源国家重点实验室, 武汉 430074 \\ * 联系人, E-mail: cqma@cug.edu.cn
}

2013-05-20 收稿, 2013-07-24 接受, 2014-01-13 网络版发表

国家重点基础研究发展计划(2012CB416800)和科技部国际科技合作项目(2007DFA21230)资助

\begin{abstract}
摘要 江苏省宁镇地区位于长江中下游沿江成矿带的最东端, 是长江中下游成矿带 的重要组成部分, 金属成矿与早白严世岩浆作用关系密切, 属于环太平洋构造岩浆成 矿带的一部分. 本次对宁镇地区中生代中酸性侵入岩体(主要为石马斑状花岗闪长岩 和高资石英闪长玢岩)进行系统的锆石 LA-ICP-MS U-Pb 定年分析, 得到了 109.1 1 1.9 101.5 $\pm 0.9 \mathrm{Ma}$ 的年龄值, 对本区中酸性侵入岩的形成时代提供了精确约束. 利用 ${ }^{40} \mathrm{Ar}-{ }^{39} \mathrm{Ar}$ 阶段加热同位素定年方法对宁镇地区磁山头铁矿床中与磁铁矿密切共 生的金云母进行了成矿时代研究，测得金云母的 ${ }^{40} \mathrm{Ar}-{ }^{39} \mathrm{Ar}$ 同位素坪年龄为 $104 \pm 1 \mathrm{Ma}$, 这代表磁山头铁矿床成矿作用发生的时间. 磁山头铁矿床矿化于早白严世, 与本区安 基山和铜山斑岩-矽卡岩型矿床形成于同一成矿事件. 综合长江中下游地区中生代侵 入岩和矿床年代学资料并结合本次研究, 认为长江中下游地区中生代存在四期 (152 135, 135 127, 127 121, 109 101 Ma)成岩成矿事件, 宁镇地区燕山期中酸性侵入 岩和矿床为区域最晚期成岩成矿作用的产物.
\end{abstract}

\section{关键词}

中生代侵入岩

LA-ICP-MS 锆石年代学

矽卡岩铁矿

${ }^{40} \mathrm{Ar}-{ }^{39} \mathrm{Ar}$ 同位素年龄

宁镇地区
长江中下游地区是我国著名的中生代铜铁硫金 矿成矿带, 成矿作用与晚中生代岩浆活动关系密切. 该带位于扬子地块东北缘，紧邻华北地块和大别造 山带. 长江中下游成矿带自西向东依次分布有鄂东、 九瑞、安庆、庐枞、铜陵、宁芜和宁镇等 7 个区段 ${ }^{[1]}$ (图 1).

精确的成岩成矿时代的厘定对于认识长江中下 游地区的岩浆岩和矿床时空分布及其形成背景有重 要意义. 近年来, 前人对长江中下游地区中生代岩浆 岩及相关矿床开展了大量的高精度年代学研究, 本 区中生代岩浆活动的时空格架已基本确定, 也积累
了不少燕山期矿床的精确同位素年龄数据 ${ }^{[4]}$. 研究认 为长江中下游地区中生代岩浆岩具有随时空演化的 地球化学特征 ${ }^{[5,6]}$, 岩浆作用和成矿作用活动时间主 体集中于 145 120 Ma 之间 ${ }^{[7,8]}$, 其中 145 135 Ma 的 岩浆活动主要发生在断隆区如铜陵地区等, 是铜金 矿化的主要时期. 135 127 Ma 的岩浆活动主要发生 在断陷区如庐枞盆地、宁芜盆地等, 是铁矿化的主要 时期 ${ }^{[4]}$. 尽管长江中下游地区近年来岩浆作用的时空 框架取得了很大的进展. 但与鄂东、九瑞、铜陵及庐 枞等地区相比, 位于长江中下游地区最东端的宁镇 地区的岩浆活动和成矿作用时代研究还相对薄弱, Ningzhen region. Chin Sci Bull, 2013, 58: 4308-4318, doi: 10.1007/s11434-013-6015-8 


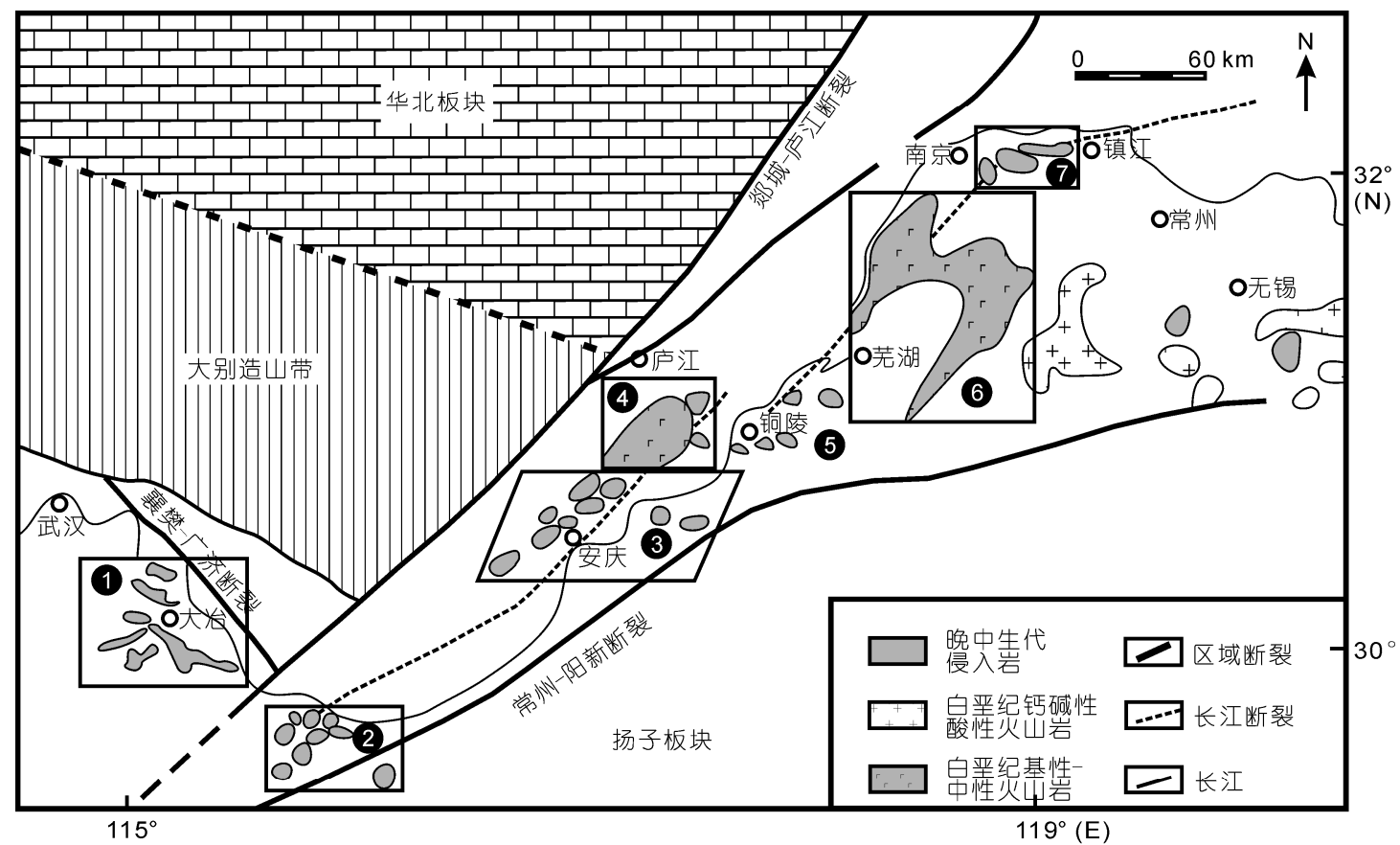

区段: 1. 鄂东, 2. 九瑞, 3. 安庆, 4. 庐枞, 5. 铜陵, 6. 宁芜, 7. 宁镇

图 1 长江中下游成矿带主要区段分布示意图

据文献[2,3]修改

前人虽然开展过较详细的研究工作, 积累了丰富的 基础地质资料 ${ }^{[9 \sim 14]}$. 但以往对宁镇地区中生代岩体主 要进行全岩 $\mathrm{K}-\mathrm{Ar}$ 和 $\mathrm{Rb}-\mathrm{Sr}$ 法定年研究, 仅最近对安 基山岩体开展了高精度年代学研究 ${ }^{[15]}$, 总体而言, 本区仍缺乏系统的年代学对比研究. 此外, 由于成矿 作用的复杂性，多期性以及同位素测年方法的局限 性, 宁镇地区中生代金属矿床的年代研究一直进展 缓慢. 这一状况不利于深人研究岩浆活动与金属成 矿作用之间的关系, 也阻碍了对长江中下游成矿带 岩浆-成矿作用时空结构的理解.

本文在详细的野外观察的基础上，对宁镇地区 燕山期的石马岩体和高资岩体开展了系统的锆石 LA-ICP-MS U-Pb 年代学研究, 同时, 对产于高资岩 体中的磁山头铁矿矿石中的金云母进行了精确的 ${ }^{40} \mathrm{Ar}-{ }^{39} \mathrm{Ar}$ 阶段加热同位素定年研究, 结合前人报道 的年龄数据, 厘定了本区成岩和成矿时代.

\section{1 地质背景}

长江中下游成矿带位于扬子地块北东缘，紧邻 华北地块和大别造山带 ${ }^{[1]}$. 其北以襄栎-广济断裂(西 段)和郯城-庐江断裂(东段)与大别造山带相分割, 其 东南以常州-阳新断裂为界(图 1). 该成矿带总体上呈

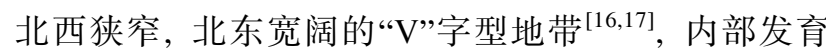
沿江分布的断裂带和北西向断裂.

长江中下游成矿带属于新元古代江南造山带的 一部分，但是就扬子陆块与华夏陆块碰撞拼合的时 间有两种意见，一是在新元古代中期约 $0.9 \mathrm{Ga}^{[18,19]}$, 另一是在新元古代中期 $0.81 \sim 0.83 \mathrm{Ga}^{[20,21]}$. 无论如何, 华南陆块整体在新元古代中期(740 780 Ma)经历了 陆内裂谷 ${ }^{[22]}$. 震旦纪之后, 长江中下游地区进人地 台型稳定沉积阶段. 从中三叠纪开始，本区进人强烈 的构造变形期; 中三叠纪受印支运动影响，本区主要 为局限海含膏盐碳酸盐岩沉积, 构成华南陆块与华 北陆块碰撞的前陆带 ${ }^{[23]}$, 之后开始大规模褶皱隆升; 至中侏罗世发育陆相盆地沉积. 晚侏罗世-白严世为 燕山期大规模构造-岩浆活动, 形成现今长江中下游 地区的主体面貌 ${ }^{[24]}$, 伴随产生大量晚中生代岩浆岩 和大规模成矿作用，其成矿作用呈现“层控”和“多位 一体”的规律 ${ }^{[16,25]}$. 长江中下游地区广泛发育的晚侏 罗-早白严世岩浆岩具有埃达克岩重要的地球化学特 征，多被称为埃达克质岩，与大规模的成矿作用密切 相关.

江苏省宁镇地区位于长江中下游沿江成矿带的 最东端, 是长江中下游成矿带的重要组成部分. 宁镇 
地区广泛分布燕山期侵人岩, 自西向东主要由 7 个同 源杂岩体组成, 分别是板仓、其林门、安基山、高资、 新桥、石马和谏壁杂岩体(图 2). 侵人岩类型齐全, 从 基性岩至酸性岩均有分布, 其中中酸性侵人岩分布 范围最广, 约占侵人岩总面积的 $80 \%^{[10]}$. 宁镇地区 内生矿产较丰富, 以铜、铁、锌等有色金属为主. 其 矿床类型主要有矽卡岩型、斑岩型和热液充填型. 矿 床主要沿近东西向背斜和近东西向断裂带分布, 构 成近东西向矿化带. 金属矿床的形成多与燕山期岩 浆侵人活动有关.

\section{2 岩体及样品特征}

石马岩体位于镇江市西南 $12 \mathrm{~km}$ 处, 呈岩株状产 出, 地表出露面积约 $34 \mathrm{~km}^{2}$, 可划分为条状山岩体、 徐湾岩体和东林场岩体. 主要岩石类型有闪长玢岩、 花岗闪长岩和正长花岗岩. 样品 09NZ09-1 为斑状花 岗闪长岩, 采自徐湾岩体的张家庄采石场. 岩石手标 本呈灰白色或略带肉红色, 块状构造. 具似斑状结构, 斑晶总量为 $30 \%$ 40\%, 斑晶以斜长石为主, 次为石 英、钾长石和少量角闪石、黑云母. 斜长石斑晶呈半 自形-自形板状, 大小一般为 $0.5 \mathrm{~mm} \times 1 \mathrm{~mm} \sim 1.2 \mathrm{~mm} \times$ $2 \mathrm{~mm}$, 聚片双晶和环带结构发育, 可见不同程度的 绢云母化. 石英斑晶呈它形粒状, 粒径一般为 0.3 $0.8 \mathrm{~mm}$, 部分可见波状消光. 钾长石斑晶呈它形粒状, 粒度为 $0.3 \sim 0.8 \mathrm{~mm}$. 黑云母斑晶呈自形片状, 片径为 0.5 1.2 mm, 也可呈叶片状集合体出现, 多已绿泥石 化, 周围常有磁铁矿和榍石析出. 角闪石斑晶呈半自 形-自形柱状, 其大小一般为 $0.4 \mathrm{~mm} \times 0.8 \mathrm{~mm} \sim 0.7 \mathrm{~mm} \times$ $1.5 \mathrm{~mm}$, 为普通角闪石, 可见简单双晶. 基质为显晶
质，主要由斜长石 $(20 \%)$ 、石英 $(20 \%)$ 、钾长石 $(15 \%)$ 、 黑云母 $(4 \%)$ 和角闪石 $(3 \%)$ 等组成, 偶见辉石. 副矿物 有磷灰石、榍石、锆石和磁铁矿等.

高资岩体呈东西向分布于宁镇中段的北部，受区 域性纵向断裂控制, 呈岩基状产出. 高资岩体可进一 步划分为下蜀和雷巷两个岩体. 其中下蜀岩体规模大, 剥蚀深, 地表出露面积约 $120 \mathrm{~km}^{2}$, 岩石类型主要有二 长花岗岩、花岗闪长岩、石英二长岩、石英闪长岩和 石英闪长玢岩等. 样品 09NZ17-1 为石英闪长玢岩, 取 自下蜀岩体的铜山铜矿附近. 岩石手标本呈灰色-灰 绿色, 块状构造. 具斑状结构, 斑晶总量为 20\% 30\%, 斑晶主要为斜长石, 其次有角闪石、黑云母和石英. 斜 长石斑晶呈半自形到自形板条状, 大小一般为 $0.3 \mathrm{~mm}$ $\times 0.5 \mathrm{~mm} \sim 0.8 \mathrm{~mm} \times 1.5 \mathrm{~mm}$, 发育聚片双晶和环带结构. 角闪石呈半自形到自形柱状或横切面呈近菱形, 为普 通角闪石, 其大小一般为 $0.2 \mathrm{~mm} \times 0.4 \mathrm{~mm} \sim 0.5 \mathrm{~mm} \times 1.0$ $\mathrm{mm}$. 石英斑晶呈它形粒状, 粒径一般为 $0.2 \sim 0.5 \mathrm{~mm}$, 部分被熔蚀成浑圆状. 黑云母斑晶呈片状, 片径一般 为 $0.3 \sim 0.6 \mathrm{~mm}$. 基质具半自形-它形微晶结构, 主要 由斜长石、石英、角闪石和黑云母组成. 副矿物有磷 灰石、榍石、锆石和磁铁矿等.

\section{3 矿床地质特征}

本文选择宁镇地区的磁山头矽卡岩型铁矿床开 展成矿时代研究. 磁山头铁矿位于下蜀南面六里甸 一带, 规模较小, 是以接触交代为主的矽卡岩型矿床, 矽卡岩化发育. 矿体主要赋存在栖霞组灰岩与中酸 性侵人岩接触带的矽卡岩中. 区内与成矿关系密切 的岩性主要为石英闪长玢岩. 矿体多呈小脉状、囊状

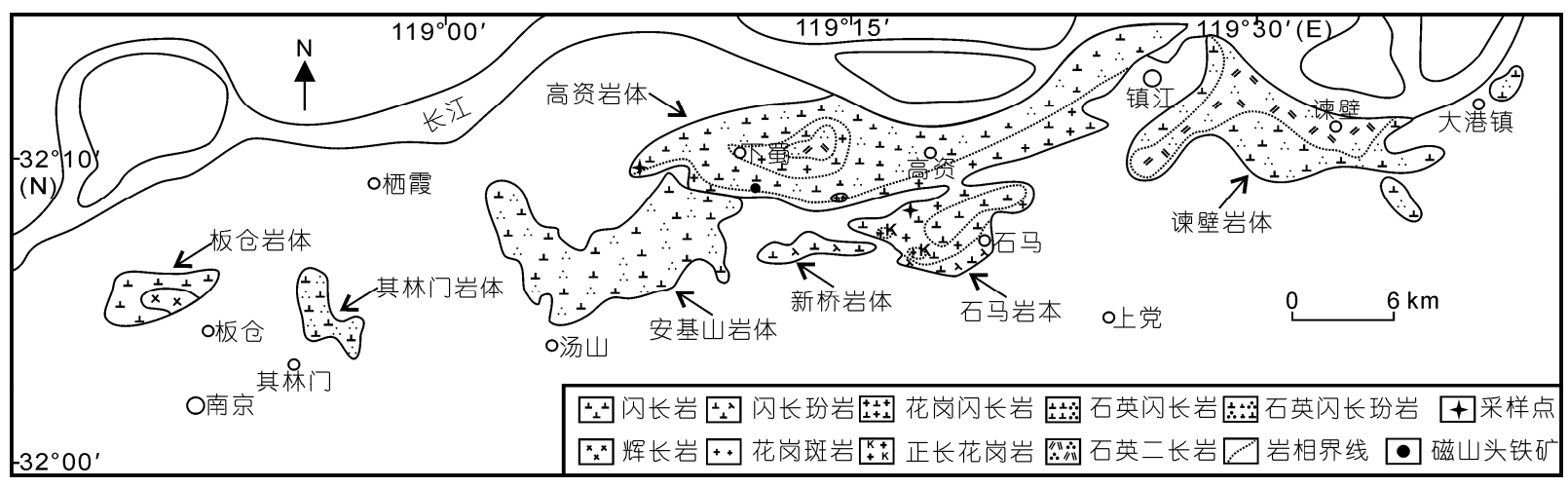

图 2 宁镇地区燕山期侵入岩分布图 据文献[13]修改 
或扁豆状, 走向以北东向为主, 倾向南东, 倾角 $50^{\circ} \sim$ $90^{\circ}$.

矿石以磁铁矿为主, 次有赤铁矿、褐铁矿、镜铁 矿、黄铁矿、黄铜矿等. 矽卡岩型矿体的矿石以块状、 浸染状、网脉状、条带状和角砾状构造为主. 具它形 粒状结构、包含结构和交代结构等. 脉石矿物主要为 金云母、透辉石、石榴子石、绿泥石、阳起石、磷灰 石和方解石等. 围岩的热液蚀变强烈(图 3(a)), 主要 有绿泥石化、金云母化、碳酸盐化、大理岩化和黄铁 矿化, 其中金云母化与磁铁矿密切相关. 本文采集来 自磁山头铁矿床中的磁铁矿岩, 磁铁矿与金云母密 切共生(图 3(b)). 金云母呈墨绿色, 大部分呈片状, 自形程度较高, 与磁铁矿共生组成块状集合体.

\section{4 分析方法}

\subsection{LA-ICP-MS 锆石 U-Pb 年代学分析}

先对 $3 \sim 5 \mathrm{~kg}$ 的岩石样品通过常规的人工破碎、 研磨、重砂和电磁分选手段进行粗选. 再在双目显微 镜下根据颜色、自形程度和形态等特征对锆石进行分 类, 挑选出代表性的锆石. 之后将选用的锆石颗粒置 于环氧树脂浇铸的样品靶上磨蚀、抛光、镀金. 通过 阴极发光 (CL) 图像分析, 确定锆石颗粒的内部结构. 锆石的反射光和透射光显微照相以及阴极发光 (CL) 显微照相均在北京离子探针中心扫描电子显微镜实 验室完成. 阴极发光 (CL) 显微照相采用的设备为美 国 GATAN 公司产 Chroma 阴极发光探头和日本产 HITACHIS300-N 型扫描电子显微镜. 为获得较准确 的年龄信息, 同位素测试选取的测试点要力求避开 锆石内部裂隙和包裹体. 先根据锆石反射光和透射
光照片初选, 再与 CL 图像反复对比, 选取同位素测 试点. 同位素测试前用体积比为 $3 \%$ 的 $\mathrm{HNO}_{3}$ 清洗样 品, 以除去样品表面的污染.

锆石的 LA-ICP-MS 年代学测试在中国地质大学 (武汉)地质过程与矿产资源国家重点实验室(GPMR) 进行, 采用 Agilent 7500a 的 ICP-MS 仪器与装配有 $193 \mathrm{~nm}$ 气体激光的 GeoLas 2005 激光剥蚀系统联机 进行, 测试采用 $\mathrm{He}$ 作为剥蚀物质的载气, 激光束斑 直径为 $32 \mu \mathrm{m}$. 同位素分馏利用锆石标样 GJ-1 作为 外标进行校正, 采用国际标准锆石 91500 外部校正法 对锆石进行分析. 微量元素含量采用美国国家标准 技术研究院研制的人工合成硅酸盐玻璃标准参考物质 NIST610 作为外标, ${ }^{29} \mathrm{Si}$ 作为内标元素进行校正. 数据 处理利用 ICPMSDataCal ${ }^{[26]}$ 完成, 使用 ComPbCorr\#3 151 对处理结果进行普通 $\mathrm{Pb}$ 校正 ${ }^{[27]}$, 年龄计算和成图 采用 Ludwig ${ }^{[28]}$ 的 ISOPLOT(ver 3.0)程序完成. 仪器参 数和详细的分析流程参见文献[29].

\section{2 金云母 ${ }^{40} \mathrm{Ar}^{39} \mathrm{Ar}$ 年代学分析}

本次研究采用 ${ }^{40} \mathrm{Ar}-{ }^{39} \mathrm{Ar}$ 同位素方法测定了磁山 头铁矿中与磁铁矿共生的金云母, 样品采自露天采 坑. 首先将样品破碎，篮选至 60 80 目大小的金云母 样品, 洗净烘干后, 在双目显微镜下挑选出纯度达到 99.9\%以上的金云母单矿物，用超声波清洗。然后 将样品与用于中子通量监测的标准样品 ZBH-2506 (荷兰自由大学标样, $132.7 \pm 0.1 \mathrm{Ma}$ )一起装人照射碟 中, 将照射碟用铝箔包好, 在真空环境中封于硅玻管 内，送至北京核反应堆照射 54 h. 样品照射后冷却 3 个月。
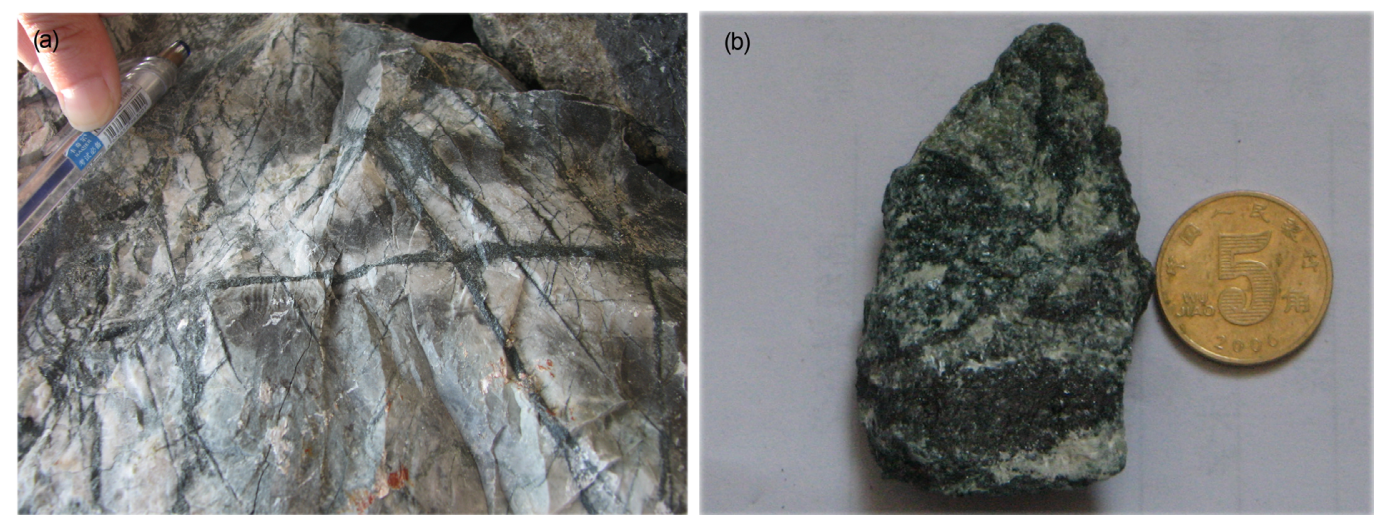

图 3 磁山头铁矿围岩蚀变强烈(a)和磁铁矿和金云母共生图(b) 
$\mathrm{Ar}$ 同位素分析在中国科学院广州地球化学研究 所同位素年代学和地球化学重点实验室的 GV-5400 气体质谱仪上完成, 每次测定未知样品之前都严格 进行系统的本底分析. 用于同位素年龄计算的 ${ }^{40} \mathrm{~K}$ 总 衰变常数采用 $5.543 \times 10^{-10} \mathrm{a}^{-1[30]}$; 中子照射过程中由 $\mathrm{Ca}$ 和 $\mathrm{K}$ 裂变所产生的同位素比值为 $\left({ }^{36} \mathrm{Ar} /{ }^{37} \mathrm{Ar}\right) \mathrm{Ca}=$ $(2.64 \pm 0.02) \times 10^{-4},\left({ }^{39} \mathrm{Ar} /{ }^{37} \mathrm{Ar}\right) \mathrm{Ca}=(7.04 \pm 0.06) \times 10^{-4},\left({ }^{40} \mathrm{Ar} /\right.$ $\left.{ }^{39} \mathrm{Ar}\right) \mathrm{K}=(8 \pm 3) \times 10^{-4} \cdot{ }^{40} \mathrm{Ar}-{ }^{39} \mathrm{Ar}$ 同位素数据处理和年龄 计算采用 ArArCALC 软件进行(ver. 2.2c) ${ }^{[31]}$. 详细的 分析流程和数据处理参见文献 $[32,33]$, 文中报道的 年龄数据为 $95 \%$ 信度水平 $(2 \sigma)$.

\section{5 测试结果}

\section{1 石马岩体}

石马岩体斑状花岗闪长岩(09NZ09-1)中的锆石 以无色-浅褐色为主. 从代表性锆石的 CL 图像(图 4) 来看, 锆石颗粒较大, 晶形完好, 均为较自形的柱状. 锆石粒径主要集中在 100 200 $\mu \mathrm{m}$ 之间, 长宽比 1:1 $3: 1$. 所有的锆石均具有清晰的内部结构和典型的岩 浆韵律生长环带.

实验过程中, 共对 15 颗锆石(15 个测试点)进行 了分析, 测试结果如表 1 所示. 15 个分析点的 Th 含
量为 370 1142 ppm (1 ppm=1 $\mu \mathrm{g} / \mathrm{g}$, 下同), $\mathrm{U}$ 含量为 431 806 ppm, Th/U 比值介于 $0.86 ~ 1.42$ 之间, 显示岩 浆成因锆石的特点. 所测 15 个点投影在谐和线上或 附近(图 5(a)), 加权平均计算得 101.6 $\pm 1.1 \mathrm{Ma}$, 代表 了斑状花岗闪长岩的形成年龄. 样品 LA-ICP-MS 锆 石 $\mathrm{U}-\mathrm{Pb}$ 同位素年龄谐和图中 ${ }^{207} \mathrm{~Pb} /{ }^{235} \mathrm{U}$ 值较分散可 能是由于 ${ }^{207} \mathrm{~Pb}$ 含量较低, 计数不准确引起的.

\section{2 高资岩体}

高资岩体石英闪长玢岩(09NZ17-1)中的锆石以 无色-浅褐色为主. 从代表性锆石颗粒的 CL 图像 (图 6)来看, 铅石晶形完好, 均为较自形的柱状. 锆 石粒径主要集中在 80 150 $\mu \mathrm{m}$ 之间, 长宽比为 $1: 1 \sim$ $3: 1$. 所有的锆石均具有清晰的内部结构和典型的岩 浆韵律生长环带.

采用 LA-ICP-MS 方法对石英闪长玢岩(09NZ171)的 15 颗锆石进行了分析, 测试结果如表 1 所示. 15 个分析点的 $\mathrm{Th}$ 含量为 459 934 ppm, U 含量为 425 759 ppm, Th/U 比值介于 $0.88 \sim 1.27$ 之间, 显示岩 浆成因锆石的特点. 在锆石 U-Pb 谐和图上(图 5(b)), 锆石的 ${ }^{206} \mathrm{~Pb} /{ }^{238} \mathrm{U}$ 变化不大, 但 ${ }^{207} \mathrm{~Pb} /{ }^{235} \mathrm{U}$ 变化范围较 广, 造成部分样品点偏离谐和线, 而基本平行于 ${ }^{207} \mathrm{~Pb} /{ }^{235} \mathrm{U}$ 坐标轴. 这可能是由于年轻锆石的放射成
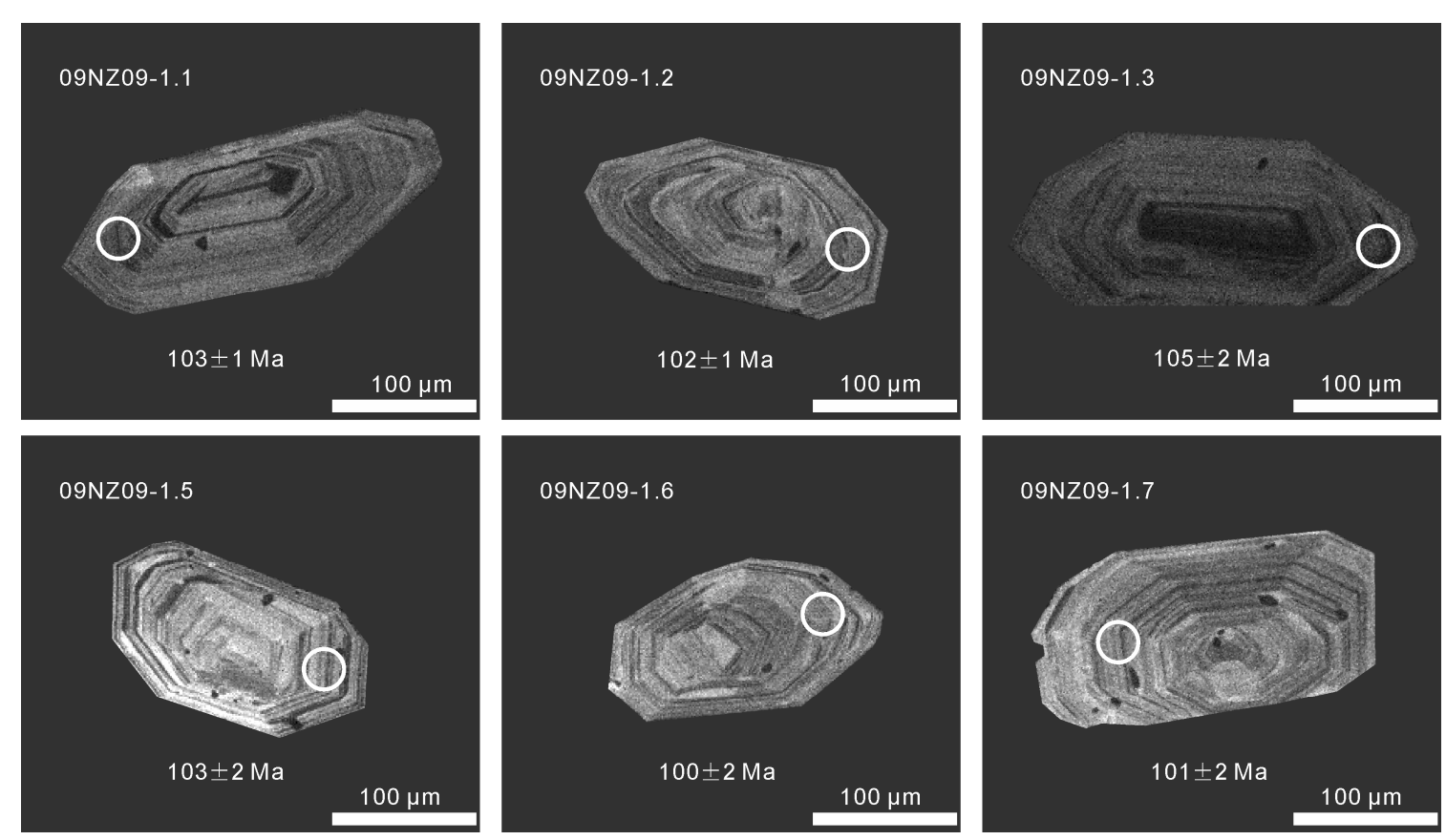

图 4 斑状花岗闪长岩(09NZ09-1)中代表性锆石的 CL 图像及测试点表面年龄 
表 1 宁镇地区中生代石马和高资岩体的 LA-ICP-MS 锆石 U-Pb 年龄分析结果

\begin{tabular}{|c|c|c|c|c|c|c|c|c|c|c|c|c|c|c|c|c|}
\hline \multirow{2}{*}{$\begin{array}{l}\text { 点 } \\
\text { 号 }\end{array}$} & \multicolumn{4}{|c|}{ 元素 (ppm) } & \multicolumn{8}{|c|}{ 同位素比值 } & \multicolumn{4}{|c|}{ 年龄 (Ma) } \\
\hline & $\mathrm{Th}$ & $\mathrm{U}$ & 总 $\mathrm{Pb}$ & $\overline{\mathrm{Th} / \mathrm{U}}$ & ${ }^{207} \mathrm{~Pb} /{ }^{206} \mathrm{~Pb}$ & $1 \sigma$ & ${ }^{207} \mathrm{~Pb} /{ }^{235} \mathrm{U}$ & $1 \sigma$ & ${ }^{206} \mathrm{~Pb} /{ }^{238} \mathrm{U}$ & $1 \sigma$ & ${ }^{208} \mathrm{~Pb} /{ }^{232} \mathrm{Th}$ & $1 \sigma$ & ${ }^{207} \mathrm{~Pb} /{ }^{235} \mathrm{U}$ & $1 \sigma$ & ${ }^{206} \mathrm{~Pb} /{ }^{238} \mathrm{U}$ & $1 \sigma$ \\
\hline \multicolumn{17}{|c|}{ 09NZ09-1 石马斑状花岗闪长岩 } \\
\hline 1 & 756 & 619 & 14.14 & 1.22 & 0.06481 & 0.00335 & 0.14342 & 0.00764 & 0.01612 & 0.00024 & 0.00505 & 0.00013 & 136 & 7 & 103 & 1 \\
\hline 2 & 741 & 593 & 13.24 & 1.25 & 0.05656 & 0.00338 & 0.12039 & 0.00665 & 0.01587 & 0.00023 & 0.00475 & 0.00015 & 115 & 6 & 102 & 1 \\
\hline 3 & 390 & 414 & 9.04 & 0.94 & 0.05882 & 0.00401 & 0.13020 & 0.00887 & 0.01647 & 0.00029 & 0.00527 & 0.00019 & 124 & 8 & 105 & 2 \\
\hline 4 & 1142 & 806 & 18.48 & 1.42 & 0.04796 & 0.00266 & 0.10255 & 0.00546 & 0.01564 & 0.00022 & 0.00471 & 0.00013 & 99 & 5 & 100 & 1 \\
\hline 5 & 478 & 520 & 11.19 & 0.92 & 0.05426 & 0.00351 & 0.11955 & 0.00752 & 0.01612 & 0.00026 & 0.00524 & 0.00020 & 115 & 7 & 103 & 2 \\
\hline 6 & 466 & 448 & 9.74 & 1.04 & 0.05021 & 0.00390 & 0.10632 & 0.00802 & 0.01566 & 0.00027 & 0.00556 & 0.00022 & 103 & 7 & 100 & 2 \\
\hline 7 & 681 & 605 & 13.78 & 1.13 & 0.06319 & 0.00438 & 0.13391 & 0.00878 & 0.01578 & 0.00025 & 0.00561 & 0.00017 & 128 & 8 & 101 & 2 \\
\hline 8 & 626 & 575 & 12.43 & 1.09 & 0.06143 & 0.00425 & 0.12768 & 0.00805 & 0.01567 & 0.00024 & 0.00508 & 0.00015 & 122 & 7 & 100 & 1 \\
\hline 9 & 414 & 446 & 9.27 & 0.93 & 0.05225 & 0.00373 & 0.11414 & 0.00808 & 0.01595 & 0.00026 & 0.00509 & 0.00019 & 110 & 7 & 102 & 2 \\
\hline 10 & 646 & 577 & 13.01 & 1.12 & 0.05391 & 0.00327 & 0.11914 & 0.00686 & 0.01630 & 0.00022 & 0.00558 & 0.00017 & 114 & 6 & 104 & 1 \\
\hline 11 & 370 & 431 & 9.19 & 0.86 & 0.06016 & 0.00412 & 0.13019 & 0.00872 & 0.01586 & 0.00028 & 0.00552 & 0.00018 & 124 & 8 & 101 & 2 \\
\hline 12 & 863 & 690 & 15.70 & 1.25 & 0.05123 & 0.00386 & 0.10885 & 0.00799 & 0.01556 & 0.00026 & 0.00489 & 0.00015 & 105 & 7 & 100 & 2 \\
\hline 13 & 1037 & 783 & 19.43 & 1.32 & 0.06388 & 0.00419 & 0.14013 & 0.00895 & 0.01606 & 0.00026 & 0.00560 & 0.00019 & 133 & 8 & 103 & 2 \\
\hline 14 & 521 & 551 & 11.56 & 0.95 & 0.05323 & 0.00350 & 0.11345 & 0.00751 & 0.01532 & 0.00024 & 0.00499 & 0.00017 & 109 & 7 & 98 & 2 \\
\hline 15 & 697 & 583 & 13.61 & 1.20 & 0.04947 & 0.00356 & 0.10764 & 0.00726 & 0.01618 & 0.00024 & 0.00519 & 0.00014 & 104 & 7 & 103 & 2 \\
\hline \multicolumn{17}{|c|}{ 09NZ17-1 高资石英闪长玢岩 } \\
\hline 1 & 497 & 460 & 10.91 & 1.08 & 0.07097 & 0.00589 & & 0.01005 & 0.01709 & 0.00049 & 0.00517 & 0.00026 & 145 & 9 & 109 & 3 \\
\hline 2 & 483 & 470 & 11.08 & 1.03 & 0.07843 & 0.00787 & 0.17871 & 0.01630 & 0.01730 & 0.00048 & 0.00499 & 0.00029 & 167 & 14 & 111 & 3 \\
\hline 3 & 571 & 496 & 11.59 & 1.15 & 0.06150 & 0.00654 & 0.13395 & 0.01222 & 0.01689 & 0.00057 & 0.00493 & 0.00033 & 128 & 11 & 108 & 4 \\
\hline 4 & 564 & 461 & 11.18 & 1.22 & 0.08205 & 0.00689 & 0.18394 & 0.01369 & 0.01725 & 0.00050 & 0.00479 & 0.00025 & 171 & 12 & 110 & 3 \\
\hline 5 & 753 & 606 & 15.18 & 1.24 & 0.06751 & 0.00568 & 0.15699 & 0.01270 & 0.01753 & 0.00045 & 0.00527 & 0.00025 & 148 & 11 & 112 & 3 \\
\hline 6 & 466 & 522 & 11.92 & 0.89 & 0.06991 & 0.00473 & 0.16223 & 0.01104 & 0.01719 & 0.00042 & 0.00548 & 0.00033 & 153 & 10 & 110 & 3 \\
\hline 7 & 552 & 567 & 12.67 & 0.97 & 0.06892 & 0.00593 & 0.15460 & 0.01202 & 0.01653 & 0.00047 & 0.00485 & 0.00029 & 146 & 11 & 106 & 3 \\
\hline 8 & 466 & 529 & 12.61 & 0.88 & 0.05817 & 0.00423 & 0.13986 & 0.00959 & 0.01778 & 0.00045 & 0.00552 & 0.00030 & 133 & 9 & 114 & 3 \\
\hline 9 & 688 & 577 & 14.57 & 1.19 & 0.07560 & 0.00592 & 0.17472 & 0.01190 & 0.01740 & 0.00040 & 0.00512 & 0.00027 & 164 & 10 & 111 & 3 \\
\hline 10 & 722 & 594 & 14.21 & 1.22 & 0.05793 & 0.00458 & 0.12217 & 0.00987 & 0.01618 & 0.00040 & 0.00517 & 0.00025 & 117 & 9 & 103 & 3 \\
\hline 11 & 459 & 425 & 10.13 & 1.08 & 0.06826 & 0.00666 & 0.14995 & 0.01265 & 0.01714 & 0.00064 & 0.00513 & 0.00035 & 142 & 11 & 110 & 4 \\
\hline 12 & 748 & 590 & 14.24 & 1.27 & 0.06696 & 0.00661 & 0.14621 & 0.01286 & 0.01610 & 0.00040 & 0.00514 & 0.00026 & 139 & 11 & 103 & 3 \\
\hline 13 & 602 & 586 & 14.35 & 1.03 & 0.06707 & 0.00578 & 0.14772 & 0.01147 & 0.01712 & 0.00042 & 0.00561 & 0.00028 & 140 & 10 & 109 & 3 \\
\hline 14 & 625 & 589 & 14.03 & 1.06 & 0.06274 & 0.00478 & 0.14208 & 0.01043 & 0.01724 & 0.00045 & 0.00492 & 0.00031 & 135 & 9 & 110 & 3 \\
\hline 15 & 934 & 759 & 19.14 & 1.23 & 0.06448 & 0.00609 & 0.14423 & 0.01014 & 0.01768 & 0.00049 & 0.00506 & 0.00024 & 137 & 9 & 113 & 3 \\
\hline
\end{tabular}
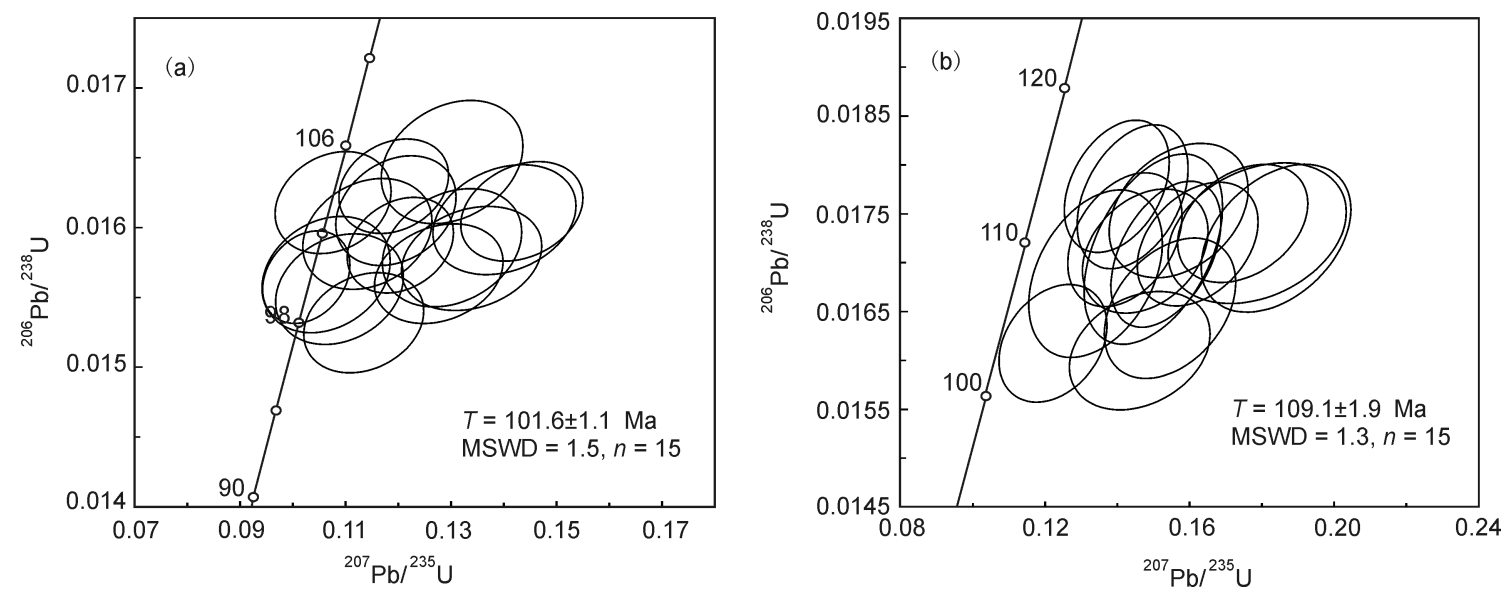

图 5 斑状花岗闪长岩(09NZ09-1) (a)和石英闪长玢岩(09NZ17-1) (b)锆石 U-Pb 谐和图 

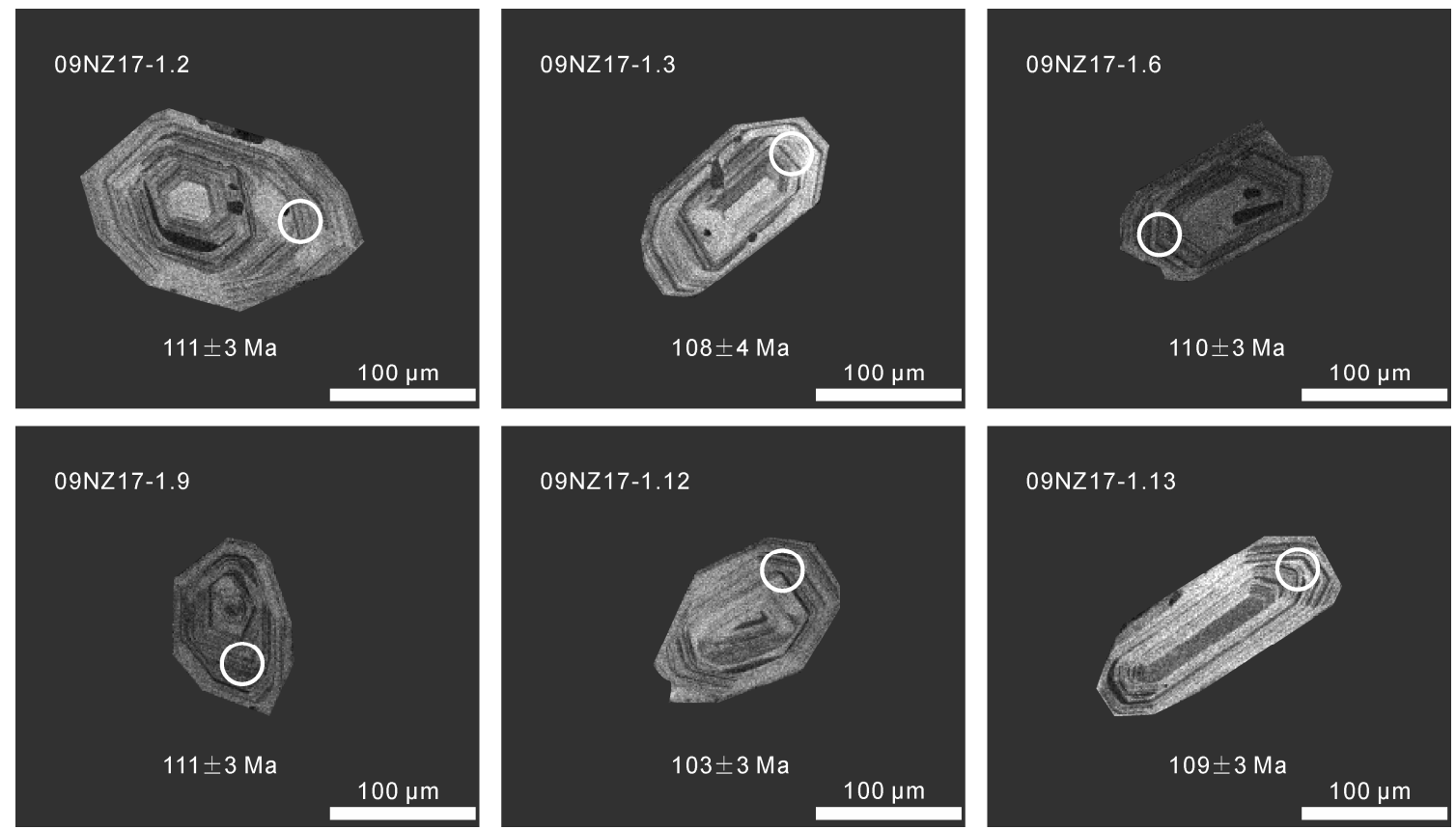

图 6 石英闪长玢岩(09NZ17-1)中代表性锆石的 CL 图像及测试点表面年龄

因 ${ }^{207} \mathrm{~Pb}$ 含量较低, 测试精度较差造成的. 锆石 ${ }^{206} \mathrm{~Pb} /$ ${ }^{238} \mathrm{U}$ 年龄均介于 $103 \sim 114 \mathrm{Ma}$ 之间，加权平均计算得 109.1 $\pm 1.9 \mathrm{Ma}$ ，代表了石英闪长玢岩的形成年龄.

\section{3 磁山头铁矿成矿时代}

与本区磁山头铁矿床中磁铁矿密切共生的金云 母 ${ }^{40} \mathrm{Ar}-{ }^{39} \mathrm{Ar}$ 同位素分析结果列于表 2 中, 相应的表观 年龄谱和等时线年龄如图 7 所示. 由图 7 可知, 对金 云母样品(09NZ33)进行了 11 个激光阶段加热分析, 获得了平坦的 ${ }^{40} \mathrm{Ar}-{ }^{39} \mathrm{Ar}$ 年龄谱, 视年龄变化范围为
94.6 104.1 Ma, 整个谱线的坪年龄为 $104 \pm 1 \mathrm{Ma}$. 利 用所有加热阶段产生的数据拟和出一条很好的等时 线，等时线年龄为 $104.2 \pm 1.2 \mathrm{Ma}$, 初始值 ${ }^{40} \mathrm{Ar} /{ }^{36} \mathrm{Ar}$ 为 $241 \pm 30, M S W D=0.2$. 在误差范围内等时线年龄和坪 年龄完全一致, 证明分析结果可靠. 样品 ${ }^{40} \mathrm{Ar} /{ }^{36} \mathrm{Ar}$ 初 始比值与大气氩比值 $295.5 \pm 5$ 存在一定程度的偏离, 可能是由于测试样品云母中放射性成因 ${ }^{40} \mathrm{Ar}$ 含量较 高(如绝大部分 $>90 \%$ )，等时线拟合时造成初始比值 ${ }^{40} \mathrm{Ar} /{ }^{36} \mathrm{Ar}$ 不准确导致 ${ }^{[34]}$. 各加热阶段所获得的视年 龄相当稳定, 且年龄坪连续、平坦, ${ }^{39} \mathrm{Ar}$ 析出量较大,

表 2 宁镇地区磁山头铁矿床中金云母 ${ }^{40} \mathrm{Ar}-{ }^{39} \mathrm{Ar}$ 年龄测定结果 ${ }^{\mathrm{a}}$

\begin{tabular}{|c|c|c|c|c|c|c|c|c|c|c|}
\hline 样品和阶段号 & 激光功率(W) & ${ }^{40} \mathrm{Ar} /{ }^{39} \mathrm{Ar}$ & ${ }^{37} \mathrm{Ar} /{ }^{39} \mathrm{Ar}$ & ${ }^{36} \mathrm{Ar} /{ }^{39} \mathrm{Ar}$ & ${ }^{40} \mathrm{Ar} /{ }^{39} \mathrm{Ar}_{\mathrm{K}}$ & ${ }^{40} \operatorname{Ar}^{*}(\%)$ & ${ }^{39} \mathrm{Ar}_{\mathrm{K}}(\%)$ & $\mathrm{K} / \mathrm{Ca}$ & 年龄 $(\mathrm{Ma})$ & $\pm 2 \sigma(\mathrm{Ma})$ \\
\hline $11 \mathrm{G} 2033 \mathrm{~B}$ & 4.50 & 9.43699 & 0.04745 & 0.00967 & 6.57667 & 69.69 & 0.00408 & 0.43 & 94.61 & 0.86 \\
\hline $11 \mathrm{G} 2033 \mathrm{C}$ & 5.00 & 8.04693 & 0.02045 & 0.00274 & 7.23507 & 89.91 & 0.00909 & 0.43 & 103.82 & 0.78 \\
\hline 11G2033D & 5.30 & 8.34939 & 0.02198 & 0.00377 & 7.23417 & 86.64 & 0.00861 & 0.43 & 103.81 & 0.52 \\
\hline $11 \mathrm{G} 2033 \mathrm{E}$ & 5.60 & 7.93758 & 0.01276 & 0.00230 & 7.25609 & 91.41 & 0.00933 & 0.43 & 104.11 & 0.48 \\
\hline $11 \mathrm{G} 2033 \mathrm{~F}$ & 6.00 & 7.80293 & 0.00558 & 0.00189 & 7.24410 & 92.84 & 0.01893 & 0.43 & 103.94 & 0.50 \\
\hline $11 \mathrm{G} 2033 \mathrm{G}$ & 6.40 & 7.77830 & 0.00930 & 0.00177 & 7.25468 & 93.27 & 0.01520 & 0.43 & 104.09 & 0.49 \\
\hline $11 \mathrm{G} 2033 \mathrm{H}$ & 6.90 & 7.73487 & 0.01488 & 0.00164 & 7.24902 & 93.72 & 0.00997 & 0.43 & 104.01 & 0.48 \\
\hline $11 \mathrm{G} 2033 \mathrm{~L}$ & 7.60 & 7.69309 & 0.01159 & 0.00150 & 7.24960 & 94.24 & 0.01202 & 0.43 & 104.02 & 0.47 \\
\hline $11 \mathrm{G} 2033 \mathrm{I}$ & 8.50 & 7.86385 & 0.04245 & 0.00215 & 7.22776 & 91.91 & 0.00350 & 0.43 & 103.72 & 0.68 \\
\hline $11 \mathrm{G} 2033 \mathrm{~J}$ & 10.00 & 8.00079 & 0.11983 & 0.00271 & 7.19757 & 89.96 & 0.00140 & 0.43 & 103.29 & 1.23 \\
\hline $11 \mathrm{G} 2033 \mathrm{~K}$ & 15.00 & 7.87279 & 0.07930 & 0.00229 & 7.19504 & 91.39 & 0.00173 & 0.43 & 103.26 & 1.81 \\
\hline
\end{tabular}

a) $09 \mathrm{NZ33}$ (参数 $J=0.0081871 \pm 0.0000409$ ) 

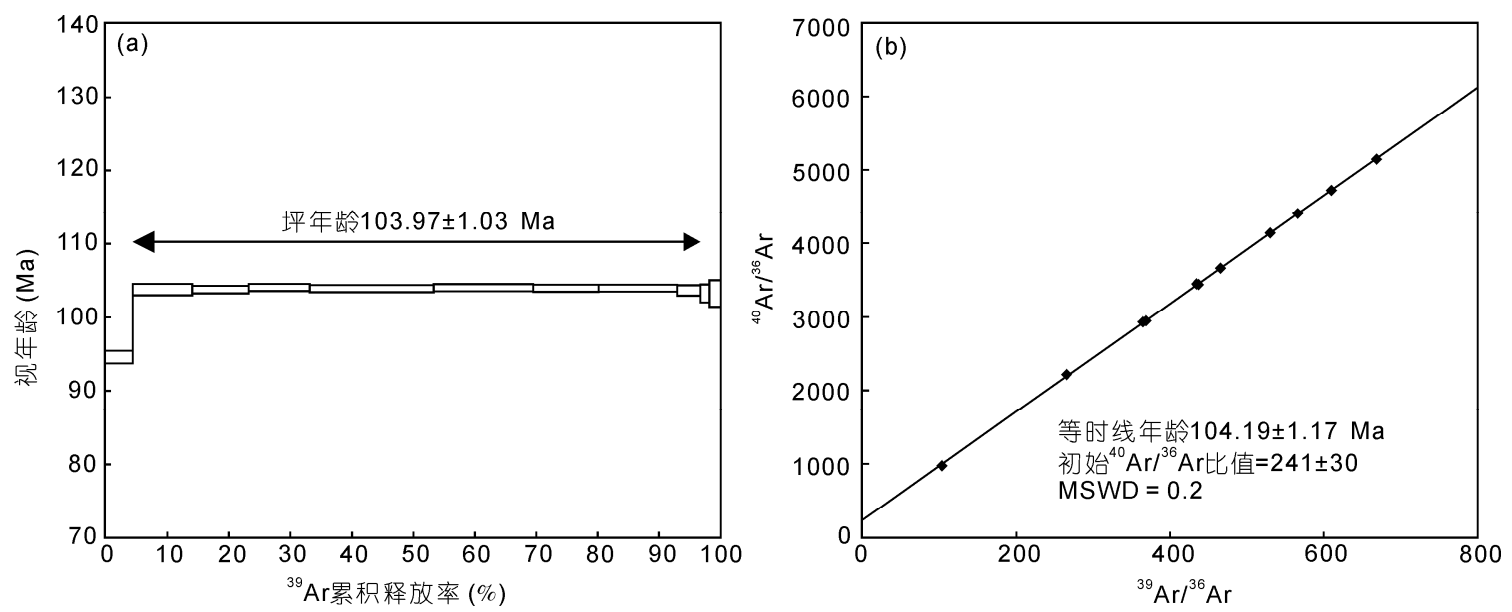

图 7 宁镇地区磁山头铁矿床中金云母 $(\mathrm{a}){ }^{40} \mathrm{Ar}-{ }^{39} \mathrm{Ar}$ 坪年龄和 $(\mathrm{b})$ 等时线年龄图

所获坪年龄可以较为准确地反映样品所经历的热事 件. 因此金云母的坪年龄 $104 \pm 1 \mathrm{Ma}$ 可以代表金云母 的冷却年龄.

\section{6 讨论}

\section{1 成岩时代}

岩体的精确测年是研究和分析其形成地球动力 学背景的基础. 以往宁镇地区燕山期侵人岩体的时 代多是利用 $\mathrm{K}-\mathrm{Ar}$ 法和 $\mathrm{Rb}-\mathrm{Sr}$ 等时线法来测定的，年 龄范围相对较宽, 有关各岩体的侵位年龄仍存在着 较大分歧：如已有的关于宁镇地区石马岩体的同位 素地质年龄(单矿物黑云母 K-Ar 法 4 件、锆石 U-Pb

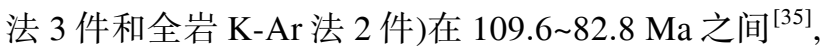
认为其为一燕山晚期的花岗质杂岩体. 叶水泉 ${ }^{[36]}$ 利 用全岩 $\mathrm{Rb}-\mathrm{Sr}$ 法测得宁镇地区伏牛山岩体中花岗闪 长斑岩的年龄为 $111 \pm 1 \mathrm{Ma}$.

本文获得的宁镇地区石马斑状花岗闪长岩和高 资石英闪长玢岩的锆石 LA-ICP-MS U-Pb 年龄分别为

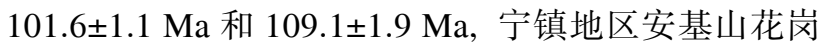
闪长斑岩的锆石 SHRIMP U-Pb 年龄为 $106.9 \pm 0.9$ $\mathrm{Ma}^{[15]}$. 这一结果表明宁镇地区中生代中酸性侵人岩 岩浆作用时限介于 109 101 Ma, 明显晚于长江中下 游其他地区的中生代岩浆作用活动时限. 因此宁镇 地区中生代中酸性侵人岩岩浆活动代表长江中下游 地区中生代岩浆活动的另一期成岩事件.

\section{2 成矿时代}

矿床的精确测年是建立矿床模型和反演成矿地
球动力学背景的基础. 矿石中的脉石矿物金云母的 ${ }^{40} \mathrm{Ar}-{ }^{39} \mathrm{Ar}$ 年龄已被广泛用来指示矿化年龄 ${ }^{[37,38]}$. 在 本文研究的磁山头铁矿床内, 金云母与磁铁矿密切 共生, 为同一矿化蚀变阶段的产物, 是精确厘定该区 铁矿化时限的理想对象. 因此, 金云母 ${ }^{40} \mathrm{Ar}-{ }^{39} \mathrm{Ar}$ 表面 年龄可以近似地代表金云母和磁铁矿的形成年龄. 本 文所测磁山头铁矿矿石中金云母的坪年龄为 $104 \pm 1$ $\mathrm{Ma}$ ，代表了磁山头铁矿床成矿作用发生的时间. 目 前, 宁镇矿区内已获得少量成矿年龄数据，如安基山 铜矿和铜山铜矿中辉钼矿的 Re-Os 等时线年龄分别 为 $108 \pm 2$ 和 $106 \pm 3 \mathrm{Ma}^{[12]}$. 本区中生代中酸性侵人岩 的形成时代为 109 101 Ma. 这表明宁镇地区中生代 中酸性侵人岩体的形成和金属成矿作用在时间上应 该是一个互相联系的过程. 本区磁山头铁矿床矿化 出现于早白严世, 与安基山和铜山斑岩-矽卡岩型铜 铁多金属矿床属于同一成矿事件, 是长江中下游成 矿带早白普世多金属成矿事件的一部分.

\section{3 成岩成矿年代学意义}

长江中下游地区是中国东部中生代大规模成岩 成矿作用的重要地区，该区的成岩成矿作用具有爆 发式和多期次的特点 ${ }^{[2,39]}$. 从 20 世纪 70 年代开始, 对长江中下游地区的中生代岩浆岩就开展了大量的 年代学研究. 本文收集了长江中下游地区已发表的 锆石 SHRIMP U-Pb 法、锆石 LA-ICP-MS U-Pb 法和 黑云母 Ar-Ar 法等高精度侵人岩年龄及利用辉钼矿 Re-Os 法和含钾矿物 Ar-Ar 法等测定的高精度成矿年 龄, 并结合本文获得的宁镇地区燕山期的成岩成矿 年龄. 统计结果(图 8)表明, 长江中下游地区中生代 

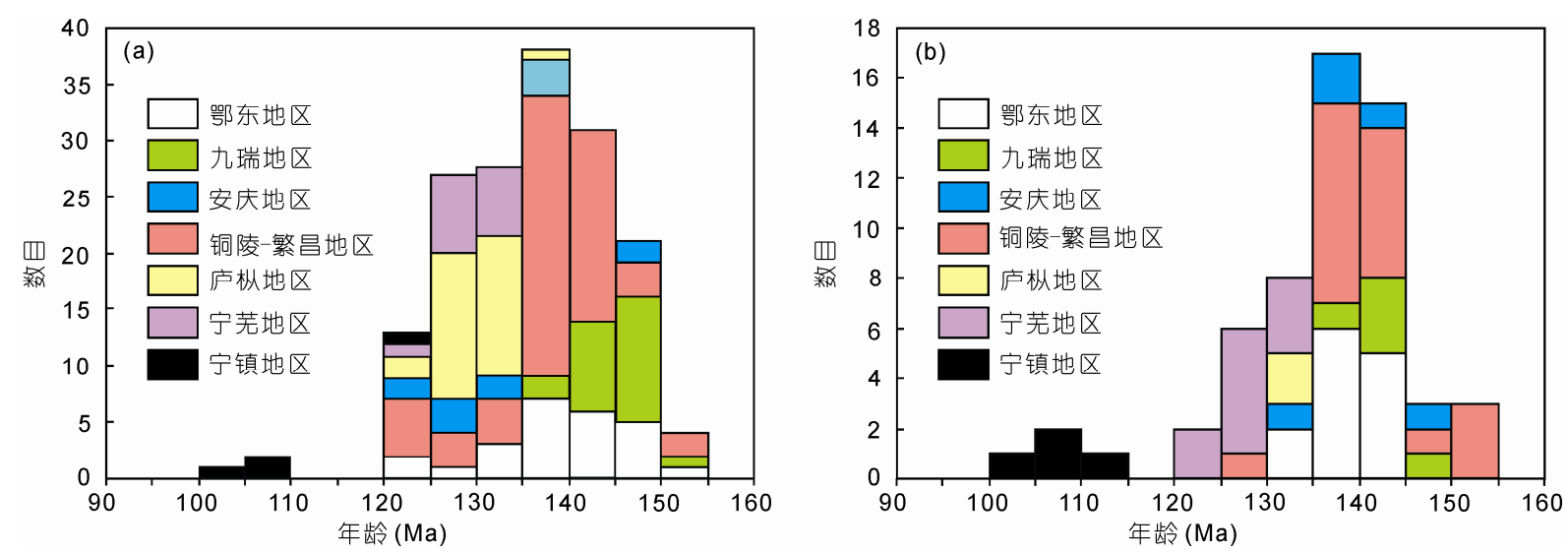

图 8 长江中下游地区中生代侵入岩时代(a)和矿床成矿时代(b)直方图 对应的年龄数据和参考文献见表 S1

侵人岩活动时限为 152 101 Ma, 峰期介于 140 135 $\mathrm{Ma}$ 之间, 与成矿年龄的范围和峰期基本一致, 反映 了长江中下游地区中生代岩浆活动与成矿作用有着 极为密切的关系.

长江中下游地区的中生代侵人岩岩浆活动时间 和成矿时代表现出明显的分区性和演化趋势，均有 自西向东年代变新的趋势(图 8). 长江中下游地区已 获得的燕山期最早的岩浆活动记录为大冶地区的殷 祖闪长-辉长岩 ${ }^{[40]}$ 和铜陵地区的沙滩角石英二长岩 ${ }^{[41]}$, 年龄约为 $152 \mathrm{Ma}$. 而本文研究的宁镇地区石马岩体属 于长江中下游地区燕山期最晚的岩浆活动(101 Ma).

综合以往长江中下游地区燕山期成岩成矿年代 学研究资料, 并结合本次关于宁镇地区中生代侵人 岩和矿床年代学研究结果, 认为长江中下游地区可 以区分出 4 期成岩成矿事件:

第一期为 152 135 Ma, 主要为分布在鄂东南、 铜陵、庐枞等地区的高钾钙碱性闪长岩类, 绝大多数 为埃达克质岩. 代表整个长江中下游地区一次显著 的岩浆活动, 是矽卡岩-斑岩型铜金矿化的主要时 期 ${ }^{[42,43]}$.

第二期为 135 127 Ma, 主要为分布在繁昌盆地、 庐枞盆地、宁芜盆地及溧水盆地的一套富碱、高钾的 粗安岩、粗面岩、安山岩及玄武岩等火山岩, 与铀、
金矿化有关 ${ }^{[7,44 \sim 46]}$.

第三期为 127 121 Ma, 规模较小, 主要为分布 在繁昌盆地、宁芜盆地及其附近的 $\mathrm{A}$ 型花岗岩和富 $\mathrm{Na}$ 基性岩. 铁矿成矿时代与这一期岩浆活动同时 代 ${ }^{[7,47]}$.

第四期为 109 101 Ma, 主要为宁镇地区高钾钙 碱性的花岗岩类. 宁镇地区铜铁矿成矿时代与这一 期岩浆活动同时代. 宁镇地区中酸性岩浆活动和成 矿事件属于长江中下游地区中生代最晚期成岩成矿 作用的产物, 对研究长江中下游地区构造-岩浆-成矿 演化具有重要意义.

\section{7 结论}

(1) 宁镇地区的燕山期中酸性侵人岩形成于 109 101 Ma, 为早白严世晚期.

(2) 宁镇地区磁山头矽卡岩型铁矿床矿化于早 白严世, 与本区安基山和铜山斑岩-矽卡岩型矿床形 成于同一成矿事件, 是长江中下游成矿带早白严世 多金属成矿事件的一部分.

(3) 长江中下游地区中生代存在四期(152 135, 135 127，127 121，109 101 Ma)成岩成矿事件, 宁镇 地区中生代中酸性侵人岩和矿床为区域最晚期成岩 成矿作用的产物. 
1 Pan Y M, Dong P. The Lower Changjiang (Yangzi/Yangtze River) metallogenic belt, east central China: Intrusion- and wall rock-hosted $\mathrm{Cu}-\mathrm{Fe}-\mathrm{Au}, \mathrm{Mo}, \mathrm{Zn}, \mathrm{Pb}, \mathrm{Ag}$ deposits. Ore Geol Rev, 1999, 15: 177-242

2 翟裕生, 姚书振, 林新多, 等. 长江中下游地区铁铜(金)成矿规律. 北京：地质出版社, 1992.1-235

3 薛怀民, 董树文, 马芳. 长江中下游地区庐(江)-枞(阳)和宁(南京)-芜(湖)盆地内与成矿有关潜火山岩体的 SHRIMP 锆石 U-Pb 年龄. 岩石学报, 2010, 26: 2653-2664

4 周涛发, 范裕, 袁峰, 等. 长江中下游成矿带地质与矿产研究进展. 岩石学报, 2012, 28: 3051-3066

5 Ma C Q, Zhang C, Liu Y Y, et al. Migrating magmatic arc and lithospheric extension: Implication for Mesozoic large-scale magmatism in the Dabieshan and southeastern China. Western Pacific Geophysics Meeting Supplement, Abstract V35A-05. Eos Transactions AGU, 2008

6 Mao J W, Xie G Q, Duan C, et al. A tectono-genetic model for porphyry-skarn-stratabound Cu-Au-Mo-Fe and magnetite-apatite deposits along the Middle-Lower Yangtze River Valley, eastern China. Ore Geol Rev, 2011, 43: 294-314

7 周涛发, 范裕, 袁峰, 等. 庐枞盆地侵人岩的时空格架及其对成矿的制约. 岩石学报, 2010, 26: 2694-2714

8 毛景文, 段超, 刘佳林, 等. 陆相火山-侵人岩有关的铁多金属矿成矿作用及矿床模型——以长江中下游为例. 岩石学报, 2012, 28: $1-14$

9 宁仁祖, 陈根生. 宁镇地区燕山期侵人岩的稀土元素特征. 地球化学, 1989, 18: 52-61

10 毛建仁, 苏郁香, 陈三元. 长江中下游中酸性侵人岩与成矿. 北京: 地质出版社, 1990. 1-191

11 徐夕生, 周金城. 镇江石马杂岩体中岩石包体的成因研究. 大地构造与成矿学, 1993, 17: 53-61

12 王立本, 季克俭, 陈东. 安基山和铜山铜(钿)矿床中辉锄矿的钭-锇同位素年龄及其意义. 岩石矿物学杂志, 1997, 16: 59-64

13 夏嘉生. 宁镇地区花岗岩类岩石谱系单位的初步划分. 江苏地质, 2000, 24: 81-86

14 Xu J F, Shinjo R, Defant M J, et al. Origin of Mesozoic adakitic intrusive rocks in the Ningzhen area of east China: Partial melting of delaminated lower continental crust? Geology, 2002, 30: 1111-1114

15 曾键年, 李锦伟, 陈津华, 等. 宁镇地区安基山侵人岩 SHRIMP 锆石 U-Pb 年龄及其地质意义. 地球科学, 2013, 38: 57-67

16 常印佛, 刘湘培, 吴昌言. 长江中下游地区铜铁成矿带. 北京: 地质出版社, 1991. 1-379

17 间峻, 陈江峰, 谢智, 等. 长江中下游地区蝌蚪山晚中生代玄武岩的地球化学研究: 岩石圈地幔性质与演化的制约. 地球化学, 2005, 34: 455-469

18 Ye M F, Li X H, Li W X, et al. SHRIMP zircon U-Pb geochronological and whole-rock geochemical evidence for an early Neoproterozoic Sibaoan magmatic arc along the southeastern margin of the Yangtze Block. Gondwana Res, 2007, 12: 144-156

19 Li X H, Li W X, Li Z X, et al. Amalgamation between the Yangtze and Cathaysia Blocks in South China: Constraints from SHRIMP U-Pb zircon ages, geochemistry and Nd-Hf isotopes of the Shuangxiwu volcanic rocks. Precambrian Res, 2009, 174: 117-128

20 Zhao J H, Zhou M F, Yan D P, et al. Reappraisal of the ages of Neoproterozoic strata in South China: No connection with the Grenvillian orogeny. Geology, 2011, 39: 299-302

21 Zhang S B, Wu R X, Zheng Y F. Neoproterozoic continental accretion in South China: Geochemical evidence from the Fuchuan ophiolite in the Jiangnan orogen. Precambrian Res, 2012, 220-221: 45-64

22 郑永飞, 张少兵. 华南前寒武纪大陆地壳的形成和演化. 科学通报, 2007, 52: 1-10

23 董树文. 长江中下游铁铜矿带成因之构造分析. 中国地质科学院院报, 1991, 23: 43-56

24 任纪舜, 杨巍然. 中国东部岩石圈结构与构造岩浆演化. 北京: 原子能出版社, 1998. 1-101

25 周涛发, 范裕, 袁峰, 等. 安徽庐枞(庐江一枞阳)盆地火山岩的年代学及其意义. 中国科学 D 辑: 地球科学, 2008, 38: 1342-1353

26 Liu Y S, Hu Z C, Gao C G, et al. In situ analysis of major and trace elements of anhydrous minerals by LA-ICP-MS without applying an internal standard. Chem Geol, 2008, 257: 34-43

27 Andersen T. Correction of common lead in U-Pb analyses that do not report ${ }^{204} \mathrm{~Pb}$. Chem Geol, 2002, 192: 59-79

28 Ludwig K R. User's Manual for Isoplot 3.00: A Geochronological Toolkit for Microsoft Excel. Berkeley: Berkeley Geochronology Center, 2003. 1-74

29 Zong K Q, Liu Y S, Gao C G, et al. In situ U-Pb dating and trace element analysis of zircons in thin sections of eclogite: Refining constraints on the ultra high-pressure metamorphism of the Sulu terrane, China. Chem Geol, 2010, 269: 237-251

30 Steiger R H, Jager E. Subcommission on geochronology: Convention on the use of decay constants in geo- and cosmochronology. Earth Planet Sci Lett, 1977, 36: 359-362

31 Koppers A A P. ArArCALC-software for ${ }^{40} \mathrm{Ar} /{ }^{39} \mathrm{Ar}$ age calculations. Comput Geosci, 2002, 28: $605-619$

32 邱华宁. 新一代 Ar-Ar 实验室建设与发展趋势: 以中国科学院广州地球化学研究所 Ar-Ar 实验室为例. 地球化学, 2006, 35: 133-140

33 Qiu H N, Jiang Y D. Sphalerite ${ }^{40} \mathrm{Ar} /{ }^{39}$ Ar progressive crushing and stepwise heating techniques. Earth Planet Sci Lett, 2007, 256: 224-232 
34 Kuiper Y D. The interpretation of inverse isochron diagrams in ${ }^{40} \mathrm{Ar}-{ }^{39} \mathrm{Ar}$ geochronology. Earth Planet Sci Lett, 2002, 203: 499-506

35 江苏省地质矿产局. 宁镇山脉地质志. 南京：江苏科学技术出版社, 1989. 1-505

36 叶水泉. 江苏宁镇伏牛山岩体的铅锶等时线年龄. 江苏地质, 1999, 23: 148-150

37 Peng J T, Zhou M F, Hu R Z, et al. Precise molybdenite Re-Os and mica Ar-Ar dating of the Mesozoic Yaogangxian tungsten deposit, central Nanling district, South China. Miner Deposita, 2006, 41: 661-669

38 Xie G Q, Mao J W, Li R L, et al. Re-Os molybdenite and Ar-Ar phlogopite dating of Cu-Fe-Au-Mo (W) deposits in southeastern Hubei, China. Miner Petrol, 2007, 90: 249-270

39 Mao J W, Wang Y T, Lehmann B, et al. Molybdenite Re-Os and albite ${ }^{40} \mathrm{Ar} /{ }^{39} \mathrm{Ar}$ dating of $\mathrm{Cu}-\mathrm{Au}-\mathrm{Mo}$ and magnetite porphyry systems in the Yangtze River valley and metallogenic implications. Ore Geol Rev, 2006, 29: 307-324

40 Li J W, Zhao X F, Zhou M F, et al. Late Mesozoic magmatism from the Daye region, eastern China: U-Pb ages, petrogenesis, and geodynamic implications. Contrib Mineral Petrol, 2009, 157: 383-409

41 Di Y J, Wu G G, Zhang D, et al. SHRIMP U-Pb Zircon geochronology of the Xiaotongguanshan and Shatanjiao intrusions and its petrological implications in the Tongling area, Anhui. Acta Geol Sin, 2005, 79: 795-802

42 Xie G Q, Mao J W, Li R L, et al. Geochemistry and Nd-Sr isotopic studies of Late Mesozoic granitoids in the southeastern Hubei Province, Middle-Lower Yangtze River belt, Eastern China: Petrogenesis and tectonic setting. Lithos, 2008, 104: 216-230

43 Li X H, Li W X, Wang X C, et al. SIMS U-Pb Zircon geochronology of porphyry Cu-Au-(Mo) deposits in the Yangtze River Metallogenic Belt, eastern China: Magmatic response to Early Cretaceous lithospheric extension. Lithos, 2010, 119: 427-438

44 Wang Q, Wyman D A, Xu J F, et al. Petrogenesis of Cretaceous adakitic and shoshonitic igneous rock in the Luzong area, Anhui Province (eastern China): Implication for geodynamics and Cu-Au mineralization. Lithos, 2006, 89: 424-446

45 袁峰, 周涛发, 范裕, 等. 庐枞盆地中生代火山岩的起源, 演化及形成背景. 岩石学报, 2008, 24: 1691-1702

46 间峻, 刘海泉, 宋传中, 等. 长江中下游繁昌-宁芜火山盆地火山岩锆石 U-Pb 年代学及其地质意义. 科学通报, 2009, 54: 1716-1724

47 Li H, Ling M X, Li C Y, et al. A-type granite belts of two chemical subgroups in central eastern China: Indication of ridge subduction. Lithos, 2012, 105: 26-36

\section{补充材料}

\section{表 S1＼cjkstart长江中下游地区中生代侵入岩年龄统计表 表 S2 长江中下游地区中生代矿床年龄统计表}

本文以上补充材料见网络版 csb.scichina.com. 补充材料为作者提供的原始数据, 作者对其学术质量和内容负责. 
表 S1＼cjkstart长江中下游地区中生代侵入岩年龄统计表

\begin{tabular}{|c|c|c|c|c|c|c|}
\hline 岩体名称 & 岩石类型 & 测试对象 & 测试方法 & 年龄 & 误差 & 参考文献 \\
\hline \multicolumn{7}{|l|}{ 鄂东地区 } \\
\hline 阮家湾 & 花岗闪长岩 & 锆石 & LA-ICPMS & 143 & 1 & \multirow{2}{*}{ [1] } \\
\hline 犀牛山 & 花岗闪长斑岩 & 锆石 & LA-ICPMS & 147 & 1 & \\
\hline 鸡笼山 & 花岗闪长斑岩 & 锆石 & SHRIMP & 138.1 & 1.9 & \multirow{2}{*}[2]{} \\
\hline 丰山 & 花岗闪长斑岩 & 锆石 & SHRIMP & 136.7 & 2.1 & \\
\hline 鸡冠嘴 & 石英闪长岩 & 锆石 & LA-ICPMS & 139 & 1 & \multirow{2}{*}[3]{} \\
\hline 铜绿山 & 石英闪长岩 & 锆石 & SHRIMP & 140 & 2 & \\
\hline 铜绿山 & 石英正长闪长玢岩 & 锆石 & SHRIMP & 146 & 2 & [4] \\
\hline 铜绿山 & 二长岩 & 锆石 & SHRIMP & 134 & 2 & [5] \\
\hline 铜绿山 & 石英二长闪长玢岩 & 锆石 & SIMS & 139.8 & 1 & \multirow{2}{*}[6]{} \\
\hline 铜山口 & 花岗闪长斑岩 & 锆石 & SIMS & 144 & 1.3 & \\
\hline $\begin{array}{l}\text { 铜山口 } \\
\end{array}$ & 花岗闪长岩 & 锆石 & SHRIMP & 140.6 & 2.4 & [7] \\
\hline $\begin{array}{l}\text { 铜山口 } \\
\end{array}$ & 花岗闪长斑岩 & 锆石 & SHRIMP & 147 & 3 & [8] \\
\hline 殷祖 & 闪长岩 & 锆石 & SIMS & 146 & 1 & [6] \\
\hline $\begin{array}{l}\text { 殷祖 } \\
\end{array}$ & 石英闪长岩 & 锆石 & SHRIMP & 151.8 & 2.8 & [7] \\
\hline 阳新 & 石英二长闪长岩 & 锆石 & SIMS & 139 & 1 & \multirow{2}{*}[6]{} \\
\hline 阳新 & 闪长岩 & 锆石 & SIMS & 141 & 1 & \\
\hline 阳新 & 石英闪长岩 & 锆石 & SHRIMP & 138.5 & 2.5 & [7] \\
\hline 阳新 & 英云闪长岩 & 角闪石 & $\mathrm{Ar}-\mathrm{Ar}$ 坪年龄 & 135.9 & 0.5 & [9] \\
\hline 灵乡 & 闪长岩 & 锆石 & SIMS & 145.5 & 1.1 & [6] \\
\hline 灵乡 & 闪长岩 & 锆石 & LA-ICPMS & 141.1 & 0.7 & \multirow{5}{*}{ [7] } \\
\hline 金山店 & 闪长岩 & 锆石 & LA-ICPMS & 132.4 & 1.3 & \\
\hline 金山店 & 二长岩岩脉 & 锆石 & LA-ICPMS & 127.5 & 1.6 & \\
\hline 金山店 & 辉长闪长岩岩脉 & 锆石 & LA-ICPMS & 121.5 & 0.6 & \\
\hline 铁山 & 闪长岩 & 锆石 & SHRIMP & 135.8 & 2.4 & \\
\hline 铁山 & 石英二长岩 & 角闪石 & $\mathrm{Ar}-\mathrm{Ar}$ 坪年龄 & 133.4 & 0.4 & [9] \\
\hline 鄂城 & 花岗岩 & 锆石 & SHRIMP & 121.2 & 3.1 & [10] \\
\hline \multicolumn{7}{|l|}{ 九瑞地区 } \\
\hline 山上湾 & 石英闪长玢岩岩脉 & 锆石 & LA-ICPMS & 139 & 1.3 & \multirow{3}{*}{ [11] } \\
\hline 山上湾 & 石英闪长玢岩岩脉 & 锆石 & LA-ICPMS & 149.2 & 2.7 & \\
\hline 山上湾 & 花岗闪长斑岩岩脉 & 锆石 & LA-ICPMS & 148.5 & 1.4 & \\
\hline 阳际山 & 石英闪长斑岩 & 锆石 & SHRIMP & 143.4 & 1.4 & \multirow{9}{*}{ [12] } \\
\hline 城门坝 & 花岗闪长斑岩 & 锆石 & LA-ICPMS & 146.6 & 1 & \\
\hline 武山 & 花岗闪长斑岩 & 锆石 & LA-ICPMS & 148 & 1 & \\
\hline 武山 & 石英闪长斑岩 & 锆石 & LA-ICPMS & 145.4 & 0.9 & \\
\hline 武山 & 煌斑岩 & 锆石 & LA-ICPMS & 143.6 & 0.9 & \\
\hline 武山 & 煌斑岩 & 锆石 & LA-ICPMS & 144.3 & 0.9 & \\
\hline 武山 & 暗色基性岩脉 & 锆石 & LA-ICPMS & 142.6 & 1 & \\
\hline 武山 & 花岗闪长斑岩 & 锆石 & LA-ICPMS & 147.3 & 0.9 & \\
\hline 武山 & 暗色基性岩脉 & 锆石 & LA-ICPMS & 144.5 & 1.2 & \\
\hline 武山 & 花岗闪长斑岩 & 锆石 & SIMS & 146.1 & 1 & {$[6]$} \\
\hline 武山 & 花岗闪长斑岩 & 锆石 & SIMS & 146 & 1 & [6] \\
\hline 武山 & 花岗闪长斑岩 & 锆石 & SIMS & 144.6 & 3.9 & [13] \\
\hline 城门山 & 花岗闪长斑岩 & 锆石 & SIMS & 144.5 & 1.2 & [6] \\
\hline Dongleiwan & 花岗门长斑岩 & 锆石 & SHRIMP & 141.5 & 1.7 & [12] \\
\hline Dongleiwan & 花岗闪长斑岩 & 锆石 & SIMS & 146 & 1 & \multirow{2}{*}[6]{} \\
\hline 邓家山 & 花岗闪长斑岩 & 锆石 & SIMS & 145.4 & & \\
\hline
\end{tabular}




\begin{tabular}{|c|c|c|c|c|c|c|}
\hline 岩体名称 & 岩石类型 & 测试对象 & 测试方法 & 年龄 & 误差 & 参考文献 \\
\hline 邓家山 & 花岗闪长斑岩 & 锆石 & SHRIMP & 138.2 & 1.8 & [14] \\
\hline 丰山洞 & 石英闪长玢岩 & 锆石 & LA-ICPMS & 149.9 & 0.9 & 马昌前, 未发表 \\
\hline 丰山洞 & 闪长玢岩 & 锆石 & LA-ICPMS & 150 & 1.2 & 马昌前, 未发表 \\
\hline \multicolumn{7}{|c|}{ 铜陵－繁昌地区 } \\
\hline 浮山 & 钾长花岗岩 & 锆石 & LA-ICPMS & 126.4 & 1.7 & \multirow{3}{*}{ [15] } \\
\hline 滨江 & 花岗岩 & 铅石 & LA-ICPMS & 124.6 & 4.7 & \\
\hline 滨江 & 花岗斑岩 & 锆石 & LA-ICPMS & 123 & 1.8 & \\
\hline 牛山 & 花岗斑岩 & 铅石 & LA-ICPMS & 121.8 & 1.9 & [16] \\
\hline 天鹅抱蛋 & 石英二长闪长岩 & 锆石 & SHRIMP & 141.3 & 1.3 & \multirow{2}{*}{ [17] } \\
\hline 铜官山 & 石英二长闪长岩 & 锆石 & SHRIMP & 141.8 & 1 & \\
\hline 铜官山 & 石英二长闪长岩 & 铅石 & SHRIMP & 139.5 & 2.9 & {$[18]$} \\
\hline 铜官山 & 石英闪长岩 & 锆石 & SHRIMP & 144.7 & 1.3 & \multirow{2}{*}{ [19] } \\
\hline 铜官山 & 石英闪长岩 & 角闪石 & Ar-Ar 坪年龄 & 136.9 & 1.4 & \\
\hline 铜官山 & 石英二长岩 & 铅石 & SHRIMP & 142.8 & 1.8 & [20] \\
\hline 铜官山 & 石英闪长岩 & 锆石 & LA-ICPMS & 137.5 & 1.1 & \multirow{2}{*}{ [21] } \\
\hline 铜官山 & 石英闪长岩 & 锆石 & LA-ICPMS & 137.5 & 1.1 & \\
\hline 铜官山 & 石英闪长岩 & 锆石 & SHRIMP & 139 & 3 & \multirow{2}{*}{ [22] } \\
\hline 铜官山 & 石英闪长岩岩脉 & 铅石 & SHRIMP & 133 & 3 & \\
\hline 小铜官山 & 石英二长闪长岩 & 铅石 & SHRIMP & 142.8 & 1.8 & [23] \\
\hline 小铜官山 & 石英闪长岩 & 锆石 & SHRIMP & 139.5 & 2.9 & [24] \\
\hline 西狮子山 & 石英闪长岩 & 铅石 & LA-ICPMS & 135.1 & 3.3 & [25] \\
\hline 冬瓜山 & 辉石二长岩 & 锆石 & SHRIMP & 148.2 & 3.1 & [23] \\
\hline 冬瓜山 & 石英二长闪长岩 & 锆石 & SHRIMP & 135.5 & 2.2 & [26] \\
\hline 冬瓜山 & 辉石二长岩 & 铅石 & SHRIMP & 148.2 & 3.1 & [23] \\
\hline 冬瓜山 & 石英二长闪长岩 & 黑云母 & $\mathrm{Ar}-\mathrm{Ar}$ 坪年龄 & 135.8 & 1.1 & [27] \\
\hline 青山脚 & 石英二长闪长岩 & 铅石 & SHRIMP & 136 & 2 & [28] \\
\hline 白芒山 & 辉石二长闪长岩 & 锆石 & SHRIMP & 138.21 & 0.82 & [29] \\
\hline 白芒山 & 辉石闪长岩 & 角闪石 & $\mathrm{Ar}-\mathrm{Ar}$ 坪年龄 & 138.9 & 0.4 & [30] \\
\hline 白芒山 & 辉石二长闪长岩 & 铅石 & SHRIMP & 139.1 & 2.3 & [26] \\
\hline 白芒山 & 辉石二长闪长岩 & 铅石 & SHRIMP & 139 & 2 & [28] \\
\hline 白芒山 & 辉石闪长岩 & 铅石 & SHRIMP & 142.9 & 1.1 & [31] \\
\hline 白芒山 & 辉石二长闪长岩 & 黑云母 & Ar-Ar 坪年龄 & 136.6 & 1.1 & [27] \\
\hline 大团山 & 石英二长闪长岩 & 锆石 & SHRIMP & 139.3 & 1.2 & \multirow{2}{*}{ [29] } \\
\hline 胡村 & 花岗闪长岩 & 锆石 & SHRIMP & 140.9 & 1.2 & \\
\hline 胡村 & 花岗闪长岩 & 铅石 & SHRIMP & 140 & 2.6 & [26] \\
\hline 胡村 & 花岗闪长岩 & 锆石 & SHRIMP & 140 & 3 & [28] \\
\hline 胡村 & 花岗闪长岩 & 黑云母 & Ar-Ar 坪年龄 & 139.8 & 0.8 & [27] \\
\hline 鸡冠山 & 石英二长闪长岩 & 铅石 & SHRIMP & 139.9 & 1.1 & [29] \\
\hline 鸡冠石 & 石英二长闪长岩 & 铅石 & LA-ICPMS & 136.1 & 3 & [25] \\
\hline 鸡冠石 & 石英二长闪长岩 & 铅石 & SHRIMP & 132.7 & 4.8 & [26] \\
\hline 鸡冠石 & 石英二长闪长岩 & 铅石 & SHRIMP & 134 & 3 & [28] \\
\hline 鸡冠石 & 花岗闪长岩 & 铅石 & SHRIMP & 135.5 & 4.4 & [24] \\
\hline 南洪冲 & 花岗闪长岩 & 锆石 & LA-ICPMS & 141.9 & 4.5 & [25] \\
\hline 南洪冲 & 花岗闪长岩 & 铅石 & LA-ICPMS & 141.2 & 1.6 & [32] \\
\hline 新桥 & 石英闪长岩 & 锆石 & SHRIMP & 140.4 & 2.2 & [33] \\
\hline 凤凰山 & 石英二长闪长岩 & 锆石 & SHRIMP & 139.4 & 1.2 & \multirow{2}{*}{ [34] } \\
\hline 凤凰山 & 花岗闪长岩 & 锆石 & SHRIMP & 141 & 1.1 & \\
\hline 凤凰山 & 花岗闪长岩 & 锆石 & SHRIMP & 124.2 & 2.3 & [23] \\
\hline 凤凰山 & 石英正长斑岩 & 锆石 & LA-ICPMS & 128.4 & 0.9 & [35] \\
\hline
\end{tabular}




\begin{tabular}{|c|c|c|c|c|c|c|}
\hline 岩体名称 & 岩石类型 & 测试对象 & 测试方法 & 年龄 & 误差 & 参考文献 \\
\hline 沙滩脚 & 花岗闪长岩 & 锆石 & LA-ICPMS & 141.4 & 1.1 & [36] \\
\hline 沙滩脚 & 石英二长斑岩 & 锆石 & SHRIMP & 151.8 & 2.6 & [23] \\
\hline 沙滩脚 & 石英二长斑岩 & 锆石 & SHRIMP & 151.8 & 2.6 & {$[20]$} \\
\hline 缪家 & 闪长玢岩 & 锆石 & LA-ICPMS & 137.3 & 2.9 & \multirow{3}{*}[25]{} \\
\hline 新华山 & 花岗闪长岩 & 锆石 & LA-ICPMS & 141 & 4.5 & \\
\hline 向阳村 & 花岗闪长岩 & 锆石 & LA-ICPMS & 141.6 & 3.7 & \\
\hline 板石岭 & 石英二长岩 & 锆石 & LA-ICPMS & 124.9 & 1.7 & {$[15]$} \\
\hline 板石岭 & 黑云母石英二长岩 & 锆石 & SHRIMP & 125.3 & 2.9 & \multirow{2}{*}[24]{} \\
\hline 滨江 & 花岗岩 & 锆石 & SHRIMP & 124.3 & 2.5 & \\
\hline 金口岭 & 石英闪长岩 & 黑云母 & Ar-Ar 坪年龄 & 137.3 & 1.4 & [37] \\
\hline 舒家店 & 辉石闪长岩 & 锆石 & LA-ICPMS & 139.2 & 2.1 & {$[38]$} \\
\hline 舒家店 & 辉石二长闪长岩 & 黑云母 & $\mathrm{Ar}-\mathrm{Ar}$ 坪年龄 & 138.2 & 4.6 & \multirow{2}{*}[27]{} \\
\hline 湖城涧 & 辉长辉绿岩 & 黑云母 & $\mathrm{Ar}-\mathrm{Ar}$ 坪年龄 & 133.7 & 0.9 & \\
\hline \multicolumn{7}{|l|}{ 安庆地区 } \\
\hline 贵池 & 钾长花岗岩 & 锆石 & LA-ICPMS & 124.6 & 2 & \multirow{4}{*}{ [39] } \\
\hline 贵池 & 石英二长岩 & 锆石 & LA-ICPMS & 132.1 & 4.7 & \\
\hline 贵池 & 钾长花岗岩 & 铅石 & LA-ICPMS & 125.9 & 1.6 & \\
\hline 茅坦 & 钾长花岗岩 & 锆石 & LA-ICPMS & 127.7 & 1.8 & \\
\hline 马头 & 花岗闪长斑岩 & 锆石 & LA-ICPMS & 147 & 2 & \multirow{2}{*}[40]{} \\
\hline 花园巩 & 石英二长岩 & 锆石 & LA-ICPMS & 127 & 1 & \\
\hline 铜山 & 石英二长斑岩 & 锆石 & LA-ICPMS & 145.1 & 1.2 & [41] \\
\hline 月山 & 石英闪长岩 & 锆石 & LA-ICPMS & 139.3 & 1.5 & [42] \\
\hline 月山 & 闪长岩 & 锆石 & SHRIMP & 138.7 & 0.5 & [43] \\
\hline 月山 & 闪长岩 & 锆石 & SHRIMP & 133.2 & 3.7 & [19] \\
\hline 月山 & 闪长岩 & 角闪石 & $\mathrm{Ar}-\mathrm{Ar}$ 坪年龄 & 135.6 & 1.4 & {$[44]$} \\
\hline 洪镇 & 二长花岗岩 & 黑云母 & $\mathrm{Ar}-\mathrm{Ar}$ 坪年龄 & 121.7 & 1.2 & [37] \\
\hline \multicolumn{7}{|l|}{ 庐枞地区 } \\
\hline 黄屯 & 闪长玢岩 & 锆石 & LA-ICPMS & 134.4 & 2.2 & \multirow{14}{*}[35]{} \\
\hline 岳山 & 二长岩 & 锆石 & LA-ICPMS & 132.7 & 1.5 & \\
\hline 拔茅山 & 二长岩 & 锆石 & LA-ICPMS & 132.7 & 1.9 & \\
\hline 尖山 & 黑云母二长岩 & 锆石 & LA-ICPMS & 132 & 1.3 & \\
\hline 龙桥 & 正长岩 & 锆石 & LA-ICPMS & 131.1 & 1.5 & \\
\hline 毛王庙 & 石英正长岩 & 锆石 & LA-ICPMS & 123.9 & 1.9 & \\
\hline 土地山 & 石英正长斑岩 & 锆石 & LA-ICPMS & 127.4 & 2.8 & \\
\hline 谢瓦泥 & 辉石二长岩 & 锆石 & LA-ICPMS & 131.6 & 1.1 & \\
\hline 罗岭 & 石英正长岩 & 锆石 & LA-ICPMS & 126.3 & 2 & \\
\hline 龙王尖 & 石英正长岩 & 锆石 & LA-ICPMS & 126.5 & 1.5 & \\
\hline 小岭 & 正长岩 & 锆石 & LA-ICPMS & 126.2 & 1.8 & \\
\hline 大缸窑 & 正长岩 & 锆石 & LA-ICPMS & 125.9 & 1.3 & \\
\hline 巴坛 & 石英正长岩 & 锆石 & LA-ICPMS & 125.1 & 1.1 & \\
\hline 焦冲 & 石英正长岩 & 锆石 & LA-ICPMS & 129.6 & 1.3 & \\
\hline 焦冲 & 正长斑岩 & 锆石 & SHRIMP & 131.5 & 1.6 & [45] \\
\hline 枞阳 & 霓辉石正长岩 & 锆石 & LA-ICPMS & 129.6 & 0.8 & \multirow{2}{*}[46]{} \\
\hline 枞阳 & 正长斑岩 & 锆石 & LA-ICPMS & 129.7 & 1.4 & \\
\hline 枞阳 & 碱性花岗岩 & 锆石 & LA-ICPMS & 124.8 & 2.2 & [47] \\
\hline 井边铜 & 安山斑岩 & 锆石 & LA-ICPMS & 133.2 & 1.7 & {$[48]$} \\
\hline 罗河-泥河 & 辉石粗安玢岩 & 锆石 & LA-ICPMS & 133.2 & 1.1 & [49] \\
\hline 巴家滩 & 正长斑岩 & 锆石 & SHRIMP & 131 & 1.1 & [45] \\
\hline 巴家滩 & 辉石二长岩 & 锆石 & SHRIMP & 133.5 & 0.6 & {$[50]$} \\
\hline
\end{tabular}




\begin{tabular}{|c|c|c|c|c|c|c|}
\hline 岩体名称 & 岩石类型 & 测试对象 & 测试方法 & 年龄 & 误差 & 参考文献 \\
\hline 巴家滩 & 辉石二长岩 & 黑云母 & $\mathrm{Ar}-\mathrm{Ar}$ 等时线 & 129 & 0.6 & \\
\hline 城山 & 碱性花岗岩 & 锆石 & LA-ICPMS & 126.5 & 2.1 & \multirow{3}{*}{ [47] } \\
\hline 花山 & 碱性花岗岩 & 锆石 & LA-ICPMS & 126.2 & 0.8 & \\
\hline 黄梅尖 & 石英正长岩 & 锆石 & LA-ICPMS & 125.4 & 1.7 & \\
\hline 沙溪 & 石英闪长斑岩 & 锆石 & LA-ICPMS & 134 & 1.5 & [46] \\
\hline 沙溪 & 石英闪长岩 & 锆石 & SHRIMP & 136 & 3 & [51] \\
\hline \multicolumn{7}{|l|}{ 宁芜地区 } \\
\hline 阴山 & 辉石闪长玢岩 & 锆石 & SHRIMP & 127.8 & 1.8 & [45] \\
\hline 凹山 & 闪长玢岩 & 锆石 & LA-ICPMS & 130.2 & 2 & \multirow{7}{*}[52]{} \\
\hline 陶村 & 闪长玢岩 & 锆石 & LA-ICPMS & 130.7 & 1.8 & \\
\hline 和尚桥 & 闪长玢岩 & 锆石 & LA-ICPMS & 131.1 & 1.5 & \\
\hline 东山 & 闪长玢岩 & 锆石 & LA-ICPMS & 131.1 & 3.1 & \\
\hline 白象山 & 闪长玢岩 & 锆石 & LA-ICPMS & 130 & 1.4 & \\
\hline 和睦山 & 闪长玢岩 & 锆石 & LA-ICPMS & 131.1 & 1.9 & \\
\hline 姑山 & 闪长玢岩 & 锆石 & LA-ICPMS & 129.2 & 1.7 & \\
\hline 宁芜盆地 & 浅成侵人岩 & 锆石 & LA-ICPMS & 123 & 1 & \multirow{6}{*}[53]{} \\
\hline 宁芜盆地 & 浅成侵人岩 & 锆石 & LA-ICPMS & 127 & 3 & \\
\hline 宁芜盆地 & 浅成侵人岩 & 锆石 & LA-ICPMS & 125 & 2 & \\
\hline 宁芜盆地 & 花岗岩 & 锆石 & SHRIMP & 127.1 & 1.2 & \\
\hline 宁芜盆地 & 花岗岩 & 锆石 & LA-ICPMS & 128.3 & 0.6 & \\
\hline Ningwu Basin & 辉长闪长岩 & 锆石 & LA-ICPMS & 128.2 & 1 & \\
\hline \multicolumn{7}{|l|}{ 宁镇地区 } \\
\hline 蒋庙 & 辉石闪长岩 & 锆石 & LA-ICPMS & 121.2 & 0.85 & 马昌前, 未发表 \\
\hline 安基山 & 花岗闪长斑岩 & 锆石 & SHRIMP & 106.9 & 0.9 & {$[54]$} \\
\hline 石马 & 斑状花岗闪长岩 & 锆石 & LA-ICPMS & 101.6 & 1.1 & \multirow{2}{*}{ 本文 } \\
\hline 下蜀 & 石英闪长玢岩 & 锆石 & LA-ICPMS & 109.1 & 1.9 & \\
\hline
\end{tabular}


表 S2 长江中下游地区中生代矿床年龄统计表

\begin{tabular}{|c|c|c|c|c|c|c|c|}
\hline 矿床名称 & 产状 & 测试对象 & 测试方法 & 年龄 & 误差 & 参考文献 & 备注 \\
\hline \multicolumn{8}{|l|}{ 鄂东地区 } \\
\hline 桃花嘴 & & 金云母 & Ar-Ar 坪年龄 & 139.9 & 1.1 & \multirow{5}{*}[2]{} & \\
\hline 桃花嘴 & & 辉钼矿 & Re-Os 模式年龄 & 138.3 & 2 & & \\
\hline 鸡冠嘴 & & 辉钼矿 & Re-Os 模式年龄 & 138.2 & 2.2 & & \\
\hline 铜绿山 & & 辉锄矿 & Re-Os 模式年龄 & 137.3 & 2.4 & & \\
\hline 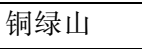 & & 金云母 & Ar-Ar 坪年龄 & 140.3 & 1.1 & & \\
\hline 铜绿山 & 矽卡岩矿石 & 辉钼矿 & Re-Os 模式年龄 & 138 & 1.7 & [55] & 2 个平均 \\
\hline $\begin{array}{l}\text { 铜山口 } \\
\end{array}$ & 斑岩型矿石 & 辉钼矿 & Re-Os 等时线年龄 & 143.8 & 2.6 & {$[56]$} & 6 个点 \\
\hline $\begin{array}{l}\text { 铜山口 } \\
\end{array}$ & 矽卡岩型矿化蚀变带 & 金云母 & $\mathrm{Ar}-\mathrm{Ar}$ 坪年龄 & 143 & 0.3 & [57] & \\
\hline 金山店 & 磁铁矿矿石 & 金云母 & Ar-Ar 坪年龄 & 131.6 & 1.2 & \multirow{2}{*}[58]{} & \\
\hline 程潮 & 磁铁矿矿石 & 金云母 & Ar-Ar 坪年龄 & 132.6 & 1.4 & & \\
\hline 阮家湾 & 花岗闪长斑岩 & 辉钼矿 & Re-Os 模式年龄 & 143.6 & 1.7 & \multirow{3}{*}[55]{} & \\
\hline 千家湾 & 矽卡岩矿石 & 辉钼矿 & Re-Os 模式年龄 & 137.7 & 1.7 & & \\
\hline 铁山 & 矽卡岩矿石 & 金云母 & $\mathrm{Ar}-\mathrm{Ar}$ 坪年龄 & 140.9 & 1.2 & & \\
\hline \multicolumn{8}{|l|}{ 九瑞地区 } \\
\hline 丰山洞 & 花岗闪长斑岩 & 辉钼矿 & Re-Os 模式年龄 & 144 & 2.1 & [55] & \\
\hline \multirow{2}{*}{ 武山 } & 蚀变花岗闪长岩 & \multirow{2}{*}{ 辉钼矿 } & \multirow{2}{*}{$\mathrm{Re}-\mathrm{Os}$ 等时线年龄 } & \multirow{2}{*}{146.4} & \multirow{2}{*}{2.6} & \multirow{2}{*}{ [59] } & \multirow{2}{*}{5 个点 } \\
\hline & 斑岩及矽卡岩 & & & & & & \\
\hline 城门山 & 矿石 & 辉锄矿 & Re-Os 模式年龄 & 142.3 & 2.3 & {$[60]$} & \\
\hline 城门山 & 石英脉 & 辉锄矿 & Re-Os 等时线年龄 & 141 & 3 & \multirow{2}{*}[61]{} & 5 个点 \\
\hline 城门山 & 石英斑岩 & 辉钼矿 & Re-Os 等时线年龄 & 137 & 3 & & 6 个点 \\
\hline \multicolumn{8}{|l|}{ 铜陵地区 } \\
\hline $\begin{array}{l}\text { 铜山南泉 } \\
\text { 鲍 }\end{array}$ & 含辉锄矿矽卡岩 & 辉钼矿 & $\mathrm{Re}-\mathrm{Os}$ 等时线年龄 & 150.7 & 1.14 & \multirow{4}{*}[62]{} & \\
\hline $\begin{array}{l}\text { 铜山南泉 } \\
\text { 鲍 }\end{array}$ & 含辉锄矿矽卡岩 & 辉钼矿 & $\mathrm{Re}-\mathrm{Os}$ 等时线年龄 & 151.22 & 1.11 & & \\
\hline 铜山前山 & 铜黄铁矿型矿石 & 黄铁矿 & $\mathrm{Re}-\mathrm{Os}$ 等时线年龄 & 148.73 & 3.22 & & \\
\hline 铜山前山 & 铜黄铁矿型矿石 & 黄铁矿 & $\mathrm{Re}-\mathrm{Os}$ 等时线年龄 & 152.5 & 6.69 & & \\
\hline 舒家店 & 黄铜矿共生 & 辉钼矿 & $\mathrm{Re}-\mathrm{Os}$ 等时线年龄 & 140.6 & 2 & {$[63]$} & \\
\hline 凤凰山 & 矿石 & 辉锄矿 & Re-Os 模式年龄 & 141.1 & 1.4 & {$[64]$} & 7 个平均 \\
\hline 朝山 & 矿石 & 磁黄铁矿 & Re-Os 等时线年龄 & 141.7 & 9.9 & [8] & \\
\hline 南阳山 & 矿石 & 辉锄矿 & Re-Os 模式年龄 & 139.1 & 1.9 & \multirow{2}{*}[60]{} & 6 个平均 \\
\hline 沙滩角 & 矿石 & 辉锄矿 & Re-Os 模式年龄 & 140 & 2 & & 5 个平均 \\
\hline 塌里牧 & 蚀变花岗闪长岩 & 辉锄矿 & Re-Os 年龄 & 138.6 & 0.2 & \multirow{2}{*}[65]{} & \\
\hline 金口岭 & 蚀变花岗闪长岩 & 辉钼矿 & $\mathrm{Re}-\mathrm{Os}$ 年龄 & 137 & 0.2 & & \\
\hline 金口岭 & 矽卡岩化辉石二长闪长岩 & 辉钼矿/黄铁矿 & $\mathrm{Re}-\mathrm{Os}$ 等时线年龄 & 137 & 0.2 & \multirow{4}{*}[66]{} & 6 个点 \\
\hline 老庙基山 & 矽卡岩带与黄铜矿磁铁矿共生 & 铬云母 & $\mathrm{Ar}-\mathrm{Ar}$ 坪年龄 & 144.9 & 0.4 & & \\
\hline 冬瓜山 & 石英脉 & 辉钼矿/黄铁矿 & Re-Os 模式年龄 & 137.4 & - & & \\
\hline 小铜官山 & 矽卡岩带中黄铜矿磁铁矿共生 & 铭云母 & Ar-Ar 坪年龄 & 135.5 & 0.5 & & \\
\hline 小铜官山 & 黄铜矿磁铁矿矽卡岩矿石 & 金云母 & Ar-Ar 坪年龄 & 144.9 & 0.4 & {$[65]$} & \\
\hline 大团山 & 矿体 & 辉钼矿 & $\mathrm{Re}-\mathrm{Os}$ 等时线年龄 & 139.1 & 2.7 & [67] & 6 个点 \\
\hline 龙虎山 & 闪长岩 & 辉锄矿 & Os-Os 模式年龄 & 138 & 2.5 & [68] & \\
\hline \multicolumn{8}{|c|}{ 安庆-贵池地区 } \\
\hline 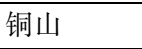 & 脉状产出矽卡岩 & 辉锄矿 & Re-Os 模式年龄 & 147.5 & 2.3 & [69] & \\
\hline 安庆 & 网脉状 & 辉钼矿 & Re-Os 模式年龄 & 138.2 & 1.9 & [60] & 4 个平均 \\
\hline
\end{tabular}




\begin{tabular}{|c|c|c|c|c|c|c|c|}
\hline 矿床名称 & 产状 & 测试对象 & 测试方法 & 年龄 & 误差 & 参考文献 & 备注 \\
\hline 铜矿里 & 矿石 & 辉锄矿 & Re-Os 模式年龄 & 141.1 & 1.9 & & 4 个平均 \\
\hline 月山 & 矿脉 & 辉锄矿 & Os-Os 模式年龄 & 136.1 & 2 & {$[68]$} & \\
\hline 月山 & 石英-硫化物阶段 & 石英 & $\mathrm{Ar}-\mathrm{Ar}$ 坪年龄 & 134.8 & 0.7 & [70] & \\
\hline \multicolumn{8}{|l|}{ 庐枞地区 } \\
\hline 龙桥 & 与黄铁矿共生 & 黑云母 & $\mathrm{Ar}-\mathrm{Ar}$ 坪年龄 & 133.4 & 1.5 & [71] & \\
\hline 井边铜 & 与黄铜矿共生 & $\begin{array}{l}\text { 石英中流体包 } \\
\text { 裹体 }\end{array}$ & $\mathrm{Ar}-\mathrm{Ar}$ 等时线年龄 & 133.2 & 3.8 & {$[48]$} & \\
\hline \multicolumn{8}{|l|}{ 宁芜地区 } \\
\hline 陶村 & 磁铁矿共生 & 金云母 & $\mathrm{Ar}-\mathrm{Ar}$ 坪年龄 & 129.3 & 1.1 & \multirow{2}{*}{ [72] } & \\
\hline 和睦山 & 磁铁矿共生 & 金云母 & $\mathrm{Ar}-\mathrm{Ar}$ 坪年龄 & 129.1 & 0.9 & & \\
\hline 和睦山 & 磁铁矿共生 & 金云母 & $\mathrm{Ar}-\mathrm{Ar}$ 坪年龄 & 132.9 & 1.1 & [73] & \\
\hline 东山 & 阳起石-磁铁矿" & 阳起石 & $\mathrm{Ar}-\mathrm{Ar}$ 坪年龄 & 127 & & \multirow{2}{*}{ [74] } & \\
\hline 凹山 & 阳起石一磁铁矿 & 阳起石 & $\mathrm{Ar}-\mathrm{Ar}$ 坪年龄 & 114 & 16 & & \\
\hline 白象山 & 磁铁矿共生 & 金云母. & $\mathrm{Ar}-\mathrm{Ar}$ 坪年龄 & 130.7 & 1.1 & [72] & \\
\hline 白象山 & 磁铁矿共生 & 金云母 & $\mathrm{Ar}-\mathrm{Ar}$ 坪年龄 & 134.9 & 1.1 & \multirow{2}{*}{ [73] } & \\
\hline 陶村 & 磁铁矿共生 & 金云母 & Ar-Ar 反等时线 & 128 & 14 & & \\
\hline 陶村 & 钠长石岩带 & 钠长石 & $\mathrm{Ar}-\mathrm{Ar}$ 坪年龄 & 124.9 & 0.3 & [75] & \\
\hline 钟山-姑山 & 中央蚀变带 & 金云母 & $\mathrm{Ar}-\mathrm{Ar}$ 坪年龄 & 126.7 & 0.2 & [76] & \\
\hline 梅山 & 钠长石岩带 & 钠长石 & $\mathrm{Ar}-\mathrm{Ar}$ 坪年龄 & 122.9 & 0.2 & [75] & \\
\hline \multicolumn{8}{|l|}{ 宁镇地区 } \\
\hline 安基山 & 细脉浸染状钿矿 & 辉锄矿 & Re-Os 模式年龄 & 108 & 2 & \multirow[b]{2}{*}{ [77] } & 2 个平均 \\
\hline $\begin{array}{ll} \\
\end{array}$ & 浸染状锄矿石 & 辉锄矿 & Re-Os 模式年龄 & 106 & 3 & & 2 个平均 \\
\hline 磁山头 & 磁铁矿共生 & 金云母 & $\mathrm{Ar}-\mathrm{Ar}$ 坪年龄 & 103.97 & 1.03 & 本文 & \\
\hline
\end{tabular}

\section{参考文献}

1 颜代蓉, 邓晓东, 胡浩, 等. 鄂东南地区阮家湾和犀牛山花岗闪长岩的时代、成因及找矿和找矿意义. 岩石学报, 2012, 28: 3373-3388

2 陈富文, 梅玉萍, 李华芹. 鄂东丰山矿田花岗闪长斑岩体锆石 SHRIMPU-Pb 定年及其意义. 地质学报, 2011, 85: 88-96

3 Xie G Q, Mao J W, Zhao H J, et al. Timing of skarn deposit formation of the Tonglushan ore district, southeastern Hubei Province, Middle-Lower Yangtze River Valley metallogenic belt and its implications. Ore Geology Reviews, 2011, 43: 62-67

4 梅玉萍, 李华芹, 陈富文. 鄂东铜绿山矿区石英正长闪长玢岩锆石 SHRIMP U-Pb 定年及其地质意义. 地球学报, 2008, 29: 805-810

5 薛怀民, 董树文, 简平. 大别山造山前陆阳新二长质侵人体的矿物化学、地球化学与锆石 SHRIMP 定年. 中国科学, D 辑: 地球科学, 2006, 36: 133-142

6 Li X H, Li W X, Wang X C, et al. SIMS U-Pb zircon geochronology of porphyry Cu-Au-(Mo) deposits in the Yangtze River Metallogenic Belt, eastern China: magmatic response to early Cretaceous lithospheric extension. Lithos, 2010, 119: 427-438

7 Li J W, Zhao X F, Zhou M F, et al. Late Mesozoic magmatism from the Daye region, eastern China:U-Pb ages, petrogenesis, and geodynamic implications. Contributions to Mineralogy and Petrology, 2008, 157: 383-409

8 Wang Q, Wyman D A, Xu J F, et al. Partial Melting of Thickened or Delaminated Lower Crust in the Middle of Eastern China: Implications for Cu-Au Mineralization. The Journal of Geology, 2007, 115: 149-161

9 周珣若, 任进. 长江中下游中生代花岗岩. 北京: 地质出版社. 1994

10 Xie G Q, Mao J W, Li R L, et al. Geochemistry and Nd-Sr isotopic studies of Late Mesozoic granitoids in the southeastern Hubei Province, Middle-Lower Yangtze River belt, Eastern China: Petrogenesis and tectonic setting. Lithos, 2008, 104: 216-230

11 徐耀明, 蒋少涌, 朱志勇, 等. 九瑞矿集区山上湾矿区石英闪长玢岩和花岗闪长斑岩的年代学、地球化学及成矿意义. 岩石学报, 2012, 28: 3306-3324

12 Yang S Y, Jiang S Y, Li L, et al. Late Mesozoic magmatism of the Jiurui mineralization district in the Middle-Lower Yangtze River Metallogenic Belt, Eastern China: Precise U-Pb ages and geodynamic implications. Gondwana Research, 2011, 20: 831-843 
13 丁昕, 蒋少涌, 倪培, 等. 江西武山和永平铜矿含矿花岗质岩体锆石 SIMS U-Pb 年代学. 高校地质学报, 2005, 11: 383-389

14 李亮, 蒋少涌. 长江中下游地区九瑞矿集区邓家山花岗闪长斑岩的地球化学与成因研究. 岩石学报, 2009, 25: 2877-2888

15 间峻, 彭戈, 刘建敏, 等. 下扬子繁昌地区花岗岩成因: 锆石年代学和 Hf-O 同位素制约. 岩石学报, 2012, 28: 3209-3227

16 唐裕禄, 间峻, 刘海泉, 等. 安徽繁昌盆地牛山岩体锆石 U-Pb 定年及其意义. 地质论评, 2010, 56: 733-738

17 吴才来，高前明，国和平，等. 铜陵地区铜官山矿田侵人岩锆石 SHRIMP 定年. 地质学报, 2010, 84: 1746-1758

18 杜杨松, 李顺庭, 曹毅, 等. 安徽铜陵铜官山矿区中生代侵人岩的形成过程一岩浆底侵、同化混染和分离结晶. 现代地质, 2007, 21: $71-77$

19 陈江峰，喻钢，杨刚，等. 安徽沿江江南晚中生代岩浆－成矿年代学格架. 安徽地质, 2005, 15: 161-169

20 Di Y J, Wu G G, Zhang D, et al. SHRIMP U-Pb Zircon geochronology of the Xiaotongguanshan and Shatanjiao intrusions and its petrological implications in the Tongling area, Anhui. Acta Geologica Sinica(English Edition), 2005, 79: 795-802

31 王彦斌, 刘敦一, 曾普胜, 等. 安徽铜陵地区幔源岩浆底侵作用的时代一朝山辉石闪长岩锆石 SHRIMP 定年. 地球学报, 2004, 25: 423-427

32 杨小男, 徐兆文, 张军, 等. 安徽狮子山矿田南洪冲岩体形成时代及成因机制研究. 岩石学报, 2007, 23: 1543-1551

33 王彦斌, 刘敦一, 蒙义峰, 等. 安徽铜陵新桥铜-硫-铁-金矿床中石英闪长岩和辉绿岩锆石 SHRIMP 年代学及其意义. 中国地质, 2004, 31: 169-173 area, Anhui Province and its geological implication. Journal of Jilin University (Earth Science Edition), 2010, 40: 581-590

\section{岩石学报, 2012, 28: 3287-3305} 周涛发, 范裕, 袁峰, 等. 庐枞盆地侵人岩的时空格架及其对成矿的制约. 岩石学报, 2010, 26: 2694-2714 吴星星, 间峻, 唐裕禄, 等. 安徽铜陵沙滩脚岩体年代学及地球化学特征. 矿物岩石, 2011, 21: 75-82 周泰禧, 陈江峰, 李学明, 等. 安徽省印支期岩浆活动质疑. 岩石学报, 1988, 4: 46-53 王世伟, 周涛发, 袁峰, 等. 铜陵舒家店岩体的年代学和地球化学特征研究. 地质学报, 2011, 85: 849-861 彭戈，间峻，初晓强，等. 贵池岩体的锆石定年和地球化学：岩石成因和深部过程. 岩石学报, 2012, 28: 3271-3286 刘园园, 马昌前, 吕昭英, 等. 长江中下游贵池矿集区燕山期岩浆作用及其地质意义: 年代学、地球化学及 Sr-Nd-Hf 同位素证据. 张智宇, 杜杨松, 张静, 等. 安徽贵池铜山岩体 SHRIMP 锆石 U-Pb 年代学与岩石地球化学特征研究. 地质论评, 2011, 57: 366-378 刘园园，马昌前，张超，等. 安徽月山闪长岩的成因探讨一锆石 U-Pb 定年及 $\mathrm{Hf}$ 同位素证据. 地质科技情报, 2009, 28: 22-30 张乐骏, 周涛发, 范裕, 等. 安徽月山岩体的锆石 SHRIMP U-Pb 定年及其意义. 岩石学报, 2008, 24: 1725-1732 陈江峰, 李学明, 周泰禧, 等. 安徽月山岩体的 40Ar/39Ar 年龄及与其有关的成矿时代估计. 现代地质, 1991, 5: 91-99 薛怀民, 董树文, 马芳. 长江中下游地区庐(江)一枞(阳)和宁(南京)一芜(湖)盆地内与成矿有关潜火山岩体的 SHRIMP 锆石 U-Pb 年 龄. 岩石学报, 2010, 26: 2653-2664 曾键年, 覃永军, 郭坤一, 等. 安徽庐枞盆地含矿岩浆岩锆石 U-Pb 年龄及其对成矿时限的约束. 地质学报, 2010, 84: 466-478 范裕, 周涛发, 袁峰, 等. 安徽庐江一枞阳地区 A 型花岗岩的 LA-ICP-MS 定年及其地质意义. 岩石学报, 2008, 24: 1715-1724 张乐骏, 周涛发, 范裕, 等. 安徽庐枞盆地井边铜矿床的成矿时代及其找矿指示意义. 岩石学报, 2010, 26: 2729-2738 覃永军, 曾键年, 曾勇, 等. 安徽南部庐枞盆地罗河一泥河铁矿田含矿辉石粗安玢岩锆石 LA-ICP-MS U-Pb 定年及其地质意义. 地 质通报, 2010, 29: 851-862 周涛发, 宋明义, 范裕, 等. 安徽庐枞盆地中巴家滩岩体的年代学研究及其意义. 岩石学报, 2007, 23: 2379-2386 
51 Wang Q, Wyman D A, Xu J, et al. Petrogenesis of Cretaceous adakitic and shoshonitic igneous rocks in the Luzong area, Anhui Province (eastern China): Implications for geodynamics and $\mathrm{Cu}-\mathrm{Au}$ mineralization. Lithos, 2006, 89: 424-446

52 范裕, 周涛发, 袁峰, 等. 宁芜盆地闪长玢岩的形成时代及对成矿的指示意义. 岩石学报, 2010, 26: 2715-2728

53 侯可军, 袁顺达. 宁芜盆地火山一次火山岩的锆石 U-Pb 年龄、 $\mathrm{Hf}$ 同位素组成及其地质意义. 岩石学报, 2010, 26: 888-902

54 曾键年, 李锦伟, 陈津华, 等. 宁镇地区安基山侵人岩 SHRIMP 锆石 U-Pb 年龄及其地质意义. 地球科学一中国地质大学学报, 2013, 38: 57-67

55 Xie G Q, Mao J W, Li R L, et al. Re-Os molybdenite and Ar-Ar phlogopite dating of Cu-Fe-Au-Mo (W) deposits in southeastern Hubei, China. Mineralogy and Petrology, 2007, 90: 249-270

56 Li J W, Zhao X F, Zhou M F, et al. Origin of the Tongshankou porphyry-skarn Cu-Mo deposit, eastern Yangtze craton, Eastern China: geochronological, geochemical, and Sr-Nd-Hf isotopic constraints. Mineralium Deposita, 2008, 43: 315-336

57 赵新福, 李建威, 马昌前. 鄂东南铁铜矿集区铜山口铜(锄)矿床 ${ }^{40} \mathrm{Ar} /{ }^{39} \mathrm{Ar}$ 年代学及对区域成矿作用的指示. 地质学报, 2006, 80: $849-862$

58 谢桂青, 毛景文, 李瑞玲, 等. 鄂东南地区大型矽卡岩型铁矿床金云母 ${ }^{40} \mathrm{Ar}-{ }^{39} \mathrm{Ar}$ 同位素年龄及其构造背景初探. 岩石学报, 2008, 24: 1917-1927

59 李进文, 李旭辉, 裴荣富, 等. 江西武山铜矿南矿带辉锄矿 Re-Os 同位素年龄及其地质意义. 地质学报, 2007, 81: 801-807

60 毛景文, Stein Holly, 杜安道, 等. 长江中下游地区铜金(锄)矿 Re-Os 年龄测定及其对成矿作用的指示. 地质学报, 2004, 78: 121-131

61 吴良士, 邹晓秋. 江西城门山铜矿铼-锇同位素年龄研究. 矿床地质, 1997, 16: 89-94

62 陈红瑾, 张静, 贾鹏飞, 等. 安徽铜山铜矿床硫化物 Re-Os 定年及其地质意义. 岩石学报, 2011, 27: 1779-1784

63 吕玉玩, 周涛发, 袁峰, 等. 安徽铜陵矿集区舒家店矿床辉钿矿 Re-Os 同位素年龄. 矿物学报, 2011, 21(S1): 621-622

64 翟泓茎, 裴荣富, 王永磊, 等. 安徽铜陵凤凰山夕卡岩型铜矿床中辉锄矿 Re-Os 同位素年龄及其地质意义. 岩石学报, 2010, 26: 785-796

65 曾普胜, 杨竹森, 蒙义峰, 等. 安徽铜陵矿集区燕山期岩浆流体系统时空结构及成矿. 矿床地质, 2004, 23: 298-309

66 蒙义峰, 杨竹森, 曾普胜, 等. 铜陵矿集区成矿流体系统时限的初步厘定. 矿床地质, 2004, 23: 271-280

67 梅燕雄, 毛景文, 李进文, 等. 安徽铜陵大团山铜矿床层状矽卡岩矿体中辉锄矿 Re-Os 年龄测定及其地质意义. 地球学报, 2005, 26: $327-331$

68 Sun W D, Xie Z, Chen J F, et al. Os-Os dating of copper and molybdenum deposits along the Middle and Lower reaches of the Yangtze River, China. Economic Geology, 2003, 98: 175-180

69 谢桂青, 赵海杰, 赵财胜, 等. 鄂东南铜绿山矿田矽卡岩型铜铁金矿床的辉钼矿 Re-Os 同位素年龄及其地质意义. 矿床地质, 2009, 28: $227-239$

70 周涛发, 袁峰, 张金金, 等. 安庆铜牛井热液脉型铜、钿、金矿床石英的 ${ }^{40} \mathrm{Ar} /{ }^{39} \mathrm{Ar}$ 快中子活化年龄. 地质论评, 2003, 49: 212-216

71 马立成, 董树文, 仲玉斌, 等. 长江中下游庐江-枞阳矿集区龙桥铁矿成矿时代研究. 地质学报, 2011, 85: 1206-1214

72 范裕, 周涛发, 袁峰. 宁芜盆地玢岩型铁矿床的成矿时代: 金云母 ${ }^{40} \mathrm{Ar}{ }^{39} \mathrm{Ar}$ 同位素年代学研究. 地质学报, 2011, 85: 810-820

73 袁顺达, 侯可军, 刘敏. 安徽宁芜地区铁氧化物－磷灰石矿床中金云母 Ar-Ar 定年及其地球动力学意义. 岩石学报, 2010, 26: 797-808

74 马芳, 蒋少涌, 薛怀民. 宁芜盆地凹山和东山铁矿床中阳起石的激光 ${ }^{39} \mathrm{Ar}-{ }^{40} \mathrm{Ar}$ 年代学研究. 矿床地质, 2010, 29: 283-289

75 余金杰, 毛景文. 宁芜玢岩铁矿钠长石 ${ }^{40} \mathrm{Ar}-{ }^{39} \mathrm{Ar}$ 定年及意义. 自然科学进展, 2002, 12: 1059-1063

$76 \mathrm{Yu} \mathrm{J} \mathrm{J}$, Mao J W. ${ }^{40} \mathrm{Ar}^{39} \mathrm{Ar}$ dating of albite and phlogopite from porphyry iron deposits in the Ningwu basins in east-central China and its significance. Acta Geologica Sinica(English Edition), 2004, 78: 435-442

77 王立本, 季克俭, 陈东. 安基山和铜山铜(钼)矿床中辉钿矿的铼-锇同位素年龄及其意义. 岩石矿物学杂志, 1997, 16: 59-64 